\title{
Amyotrophic Lateral Sclerosis: An Introduction to Treatment and Trials
}

\author{
Martin H. Maurer \\ Dept. of Physiology and Pathophysiology, University of Heidelberg
}

Germany

\section{Introduction}

There are several synonyms for Amyotrophic Lateral Sclerosis (ALS) which include Motor Neuron Disease (MND), Charcot's disease, and Lou Gehrig's disease. The latter is named after the American baseball professional Lou Gehrig, who died of ALS in the 1940s (Miller, 2011).

The symptoms of motor neuron disease (MND) have first been described by several neurologists by the mid-19th century. The French neurologist Charcot defined the nosological entity "amyotrophic lateral sclerosis" (ALS) some years later (historic aspects of ALS are reviewed in (Eisen, 2007; Mitsumoto et al., 2006; Oliveira \& Pereira, 2009; Rowland, 2001; Wijesekera \& Leigh, 2009)).

In the present understanding, MND comprehends a spectrum of different neurodegenerative syndromes which show a common neuropathology, i. e. the progressive degeneration of motor neurons.

These syndromes include the "classical" ALS, progressive bulbar palsy (PBP), progressive muscular atrophy (PMA), primary lateral sclerosis (PLS), flail arm syndrome (VulpianBernhardt syndrome), flail leg syndrome, and ALS with multi-system involvement (e.g., FrontoTemporal Dementia, FTD) (Fig. 1) (reviewed in Lillo \& Hodges, 2009; Silani et al., 2011).

\section{Diagnostic criteria}

\subsection{Clinical features}

The diagnosis of ALS is based on a catalogue of criteria specified by the World Federation of Neurology (www.wfneurology.org). These criteria are known as the "El Escorial" criteria, named after the Spanish historic site El Escorial. The original criteria of 1994 (Brooks, 1994; Mitsumoto, 1997) have been revised in 1998 (Brooks et al., 2000; Ross et al., 1998), which are known as the "Airlie House" criteria, named after the conference site at Warrenton, VA, U.S.A. In 2006, a consensus conference at Awaji-shima defined criteria of electromyographic and nerve conduction measurements for the diagnosis of ALS (de Carvalho et al., 2008).

The clinical features comprehend the presence of (i) lower motorneuron (LMN) signs such as the loss of muscle strength, muscular atrophy, fasciculations, hyporeflexia, hypotonicity or flaccidity, or muscle cramps, in at least two limbs; (ii) upper motorneuron (UMN) signs such as extensor plantar responses, spasticity, or pathologic hyperreflexia, in at least one region (bulbar, cervical, or lumbosacral), and (iii) the progression of the disease defined as increasing symptomatic impairment by history in the same region or new regions (Ferguson \& Elman, 2007). 


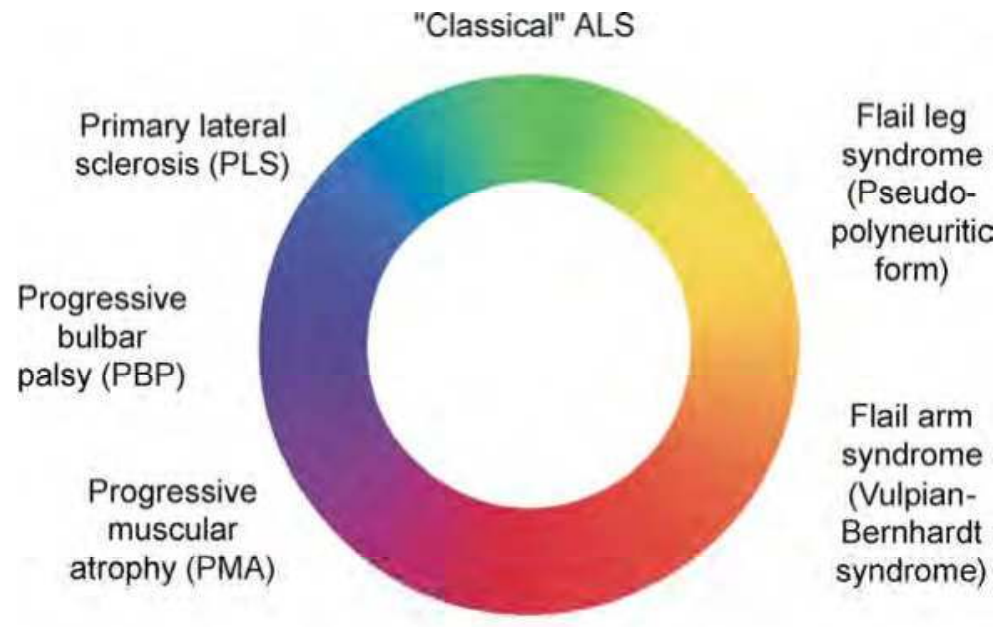

\section{ALS with multi-system involvement (e.g., Frontotemporal Dementia FTD)}

Fig. 1. Spectrum of motor neuron disease (MND). Currently, the understanding of MND comprehends a variety of neurodegenerative syndromes with progressive degeneration of motor neurons.

Neuropathological findings defining the MND spectrum are, on the cellular level, the progressive degeneration of upper and/or lower motor neurons, respectively, and on the molecular level, the presence of intraneuronal inclusion bodies which are immunopositive for ubiquitin- $(\mathrm{Ub})$ and the $43 \mathrm{kB}$ TAR DNA-binding protein (TDP-43) (reviewed in Colombrita et al., 2011; Geser et al., 2010), named Bunina, or Hirano, inclusion bodies (Rowland, 2009).

Moreover, sensory signs (except those attributable to aging), neurogenic sphincter abnormalities, other progredient diseases of the central nervous system (CNS) or peripheral nervous system (PNS) must be absent. Additionally, ALS-like syndromes must be ruled out. These include myelopathy, structural lesions of the spinal cord, multifocal motor neuropathy, hyperthyroidism, hyperparathyroidism, hematologic malignancy associated with monoclonal gammopathy, lead poisoning, a history of radiation to the CNS, and hexosaminidase A deficiency in patients younger than 30 years of age.

The revised criteria defined a certain probability level for the diagnostic criteria (Brooks et al., 2000), which have been questioned by the later electrophysiological consensus (de Carvalho et al., 2008; Sathasivam, 2010).

At present, a consensus conference has defined morphological markers by MRI, which may lead to a biomarker for ALS diagnosis (Kiernan et al., 2011; Turner et al.).

\subsection{Neuropsychiatry of ALS}

Only in recent years, psychiatric and behavioural symptoms of ALS patients came into the focus of interest. It has become clear that psychiatric symptoms are not only secondary phenomena of a disabilitating disease, but are also inherent and specific in ALS. On the other hand, the etiopathological connections remain unknown. 
With regard to the diagnoses and prevalence of these in ALS patients, there are only few data available, which are summarized in Table 1.

\begin{tabular}{|c|c|}
\hline Psychiatric Diagnosis & $\begin{array}{c}\text { Prevalence (percentages, rounded) and } \\
\text { reference }\end{array}$ \\
\hline Depression & $\begin{array}{c}\text { 30(Atassi et al., 2011; Lillo et al., 2011); 15 } \\
\text { (Ferentinos et al., 2011); 10 (Kurt et al., } \\
\text { 2007) }\end{array}$ \\
\hline Dementia & 10 (Lillo et al., 2011) \\
\hline Stereotypical behavior & 20 (Lillo et al., 2011) \\
\hline Reduction in motivation & 80 (Lillo et al., 2011) \\
\hline Apathy & 40 (Lillo et al., 2011) \\
\hline Cognitive impairment & 50 (Woolley \& Jonathan, 2008) \\
\hline Sleep disturbances & Unknown (Hetta \& Jansson, 1997) \\
\hline Fatigue & Unknown \\
\hline Psychosis & Unknown \\
\hline
\end{tabular}

Table 1. Common psychiatric symptoms and diagnoses reported in ALS patients.

In the following paragraphs, I will shortly describe the major psychiatric abnormalities in ALS patients and current findings.

\subsubsection{Dementia}

In the concept of a "continuum" of TDP-43 proteinopathies (Geser et al., 2009), ALS is classified together with fronto-temporal dementia (Giordana et al., 2011; Lillo \& Hodges, 2009; Nakano, 2000; Woolley \& Jonathan, 2008; Yoshida, 2004; Zago et al., 2011). This has also been shown on the morphological level (Tsujimoto et al., 2011).

Another pathophysiological pathway discussed in the pathogenesis of FTD is the progranulin pathway (Sleegers et al., 2010).

Cognitive impairment and frontal lobe dysfunction is seen in about $40-60 \%$ of ALS patients (Abrahams et al., 1996; Evdokimidis et al., 2002; Witgert et al., 2009).

\subsubsection{Sleep}

In the current understanding, it is difficult to distinguish whether psychiatric abnormalities in ALS patients are integral part of the CNS disease, or if they are a secondary phenomenon. For example, sleep disturbances are a common problem in ALS patients, but besides anxiety, they may also result from reduced mobility, muscle cramps, or swallowing problems (Hetta \& Jansson, 1997).

\subsubsection{Fatigue}

Fatigue is also a common problem in ALS patients, which does not describe physical exhaustion, but a pathological state of mind (Jackson \& Bryan, 1998; Lou, 2008). 


\subsubsection{Depression and anxiety}

The patients know about the devastating nature of ALS with only a short survival time remaining at the point of time at diagnosis, with a deteriorating quality of life, and without a pharmacological treatment option towards "healing". Therefore, a high prevalence of depression and anxiety in ALS patients would be expected. On the other hand, prevalence rates for depression in ALS patients range from $0-44 \%$ in the literature, whereas structured interviewing according to DSM-IV criteria reveals rates of 9-11\% (Averill et al., 2007; Ferentinos et al., 2011; Kurt et al., 2007). Prevalence rates for anxiety in ALS have been reported with $0-30 \%$ (Kurt et al., 2007). Interestingly, the rate of depression and anxiety is not as high as expected (Huey et al., 2010; McLeod \& Clarke, 2007; Norris et al., 2010), which means that the quality of life addressed by an individual is not dependent on the remaining lifetime.

\subsubsection{Psychosis}

The association of schizophrenia with ALS has been reported (Enns et al., 1993; Howland, 1990; Yase et al., 1972), but the pathophysiological interrelation remains unknown. There have been reports on a familial association (Burnstein, 1981).

\section{Measuring the disease}

The use of ALS assessment techniques such as rating scales is to monitor disease progression, to make outcome parameters in clinical trials comparable; and to predict efficacy of therapeutic strategies (Cudkowicz et al., 2004).

Typical ALS assessment techniques comprehend (i) global scales which are based on clinical observation, (ii) measuring of the muscular strength, (iii) electrophysiological testing, and (iv) the assessment of the quality of life.

\subsection{Clinical assessment scales}

Global scales subsume (i) scores based on subjective or historic data, such as the ALS functional rating scale (ALSFRS) (Cedarbaum \& Stambler, 1997; The ALS CNTF treatment study (ACTS) phase I-II Study Group, 1996), and the ALS severity scale (ALSSS) (Hillel et al., 1989), (ii) scores based on clinical tests such as the Norris scale (Norris et al., 1974), or the Appel scale (Appel et al., 1987), and (iii) scales used both for ALS and other diseases such as the Schwab and England global rating scale (Schwab \& England, 1969), or the modified Ashworth spasticity scale (Bohannon \& Smith, 1987).

\subsection{Muscular function testing}

Measuring of the muscular strength includes quantitative tests, maximum voluntary isometric contraction, handheld dynamometry, Jamar grip strength, manual muscle testing. Moreover, the spirometric measurement of the forced vital capacity and maximum voluntary ventilation can also be included in muscle tests.

\subsection{Electrophysiological measurements}

Electrophysiological testing includes compound muscle action potentials (CMAPs) and motor unit number estimate (MUNE) (Shefner et al., 2011) or the motor unit number index (MUNIX) (Nandedkar et al., 2010; Neuwirth et al., 2011). 
A consensus conference has defined electrophysiological criteria for the diagnosis of ALS (de Carvalho et al., 2008).

\subsection{Assessment of the quality of life}

The quality of life is assessed by questionnaires such as the Short form - 36 (SF-36), Short form - 12 (SF-12), ALSQ-40, or the Sickness Impact Profile (reviewed in Epton et al., 2009; McGuire et al., 1997; Williams et al., 2008).

\section{The pathophysiological rationale for therapeutic interventions}

\subsection{Pathophysiology of motor neuron degeneration in ALS}

Pathophysiological mechanisms involved in ALS include (reviewed in Mitsumoto et al., 2006; Wijesekera \& Leigh, 2009):

- genetic factors (reviewed in Pasinelli \& Brown, 2006; Robberecht, 2002; Ticozzi et al., 2011),

- $\quad$ excitotoxicity (reviewed in Bogaert et al., 2011; Foran \& Trotti, 2009),

- oxidative stress (reviewed in Kaur \& Ling, 2008; Orrell et al., 2008),

- mitochondrial and SOD1 dysfunction (reviewed in Benatar, 2007; Shi et al., 2010; Valentine et al., 2005),

- impaired axonal transport (reviewed in Costa et al., 2010),

- apoptosis and cell death (reviewed in Sathasivam et al., 2001),

- neurofilament and protein aggregation such as TDP-43 proteinopathies (reviewed in Geser et al., 2010; Worrall et al., 2000),

- neuro-inflammation (reviewed in Graber \& Dhib-Jalbut, 2009; Holmoy, 2008; Lipton et al., 2007; Weydt \& Moller, 2005), and

- the lack or dysfunction of neurotrophic factors (reviewed in Maurer et al., 2008; Siciliano et al., 2010; Traynor et al., 2006).

These pathophysiological mechanisms all end in motor neuron degeneration as the final pathway in disease progression (reviewed in Bruijn et al., 2004; Carlesi et al., 2011; Thatte \& Dahanukar, 1997).

To address the genetic influence in ALS, two databases have been established. The ALSoD database (alsod.iop.kcl.ac.uk) contains detailed information about genes involved in ALS pathophysiology, and the ALSGene database lists genetic association studies (www.alsgene.org) (Lill et al., 2011).

\subsection{Pathophysiological considerations in the planning of ALS treatment strategies}

Most pre-clinical trials in ALS research started with the pathophysiological model of the disease. In counteracting the pathophysiology of the disease, motor neuron survival and stabilization of motor neuron function is increased (reviewed in Bedlack et al., 2007; Carlesi et al., 2011; Fornai et al., 2011; Ilieva et al., 2009; Pradat et al., 2010; Silani et al., 2011).

Current strategies for treatment concepts reach for counteracting the individual pathophysiological actors. They including the following groups of agents:

- Anti-excitotoxicitory drugs. Excitotoxicity is mainly modulated by the release of glutamate and contributes to an acute toxicity. Typical molecules involved are the NMDA and AMPA receptors and the glial glutamate transporter Excitatory amino-acid 
transporters type-2 (EAAT2), which is regulating most of the extracellular glutamate concentration.

- Anti-aggregation drugs. Cellular aggregates of proteins, such as the Bunina bodies, occur in the neuronal somata of ALS patients. The prevention of these cellular aggregates may also increase the survival of motor neurons. The subcellular component involved in the degradation of aggregates is the endoplasmic reticulum (ER). Defects in ER function may contribute to the formation of the protein aggregates, as well as the inhibition of the proteasome.

- Suppliers of cellular energy. In ALS, mitochondrial dysfunction contributes to the cellular energy loss. Thus the prevention of neuronal energy depletion may increase and prolong neuronal survival.

- Anti-oxidants. The generation of reactive oxygen species (ROS), such as $\mathrm{H}_{2} \mathrm{O}_{2}$, can produce major damage to the neuron. Thus specialized cellular systems exist in the cell to prevent oxidative damage. One of these systems include $[\mathrm{Cu}, \mathrm{Zn}]$-superoxide dismutase-1 (SOD1), of which mutations in humans can induce ALS.

- SOD1 reduction techniques. The clearance of the mutated and dysfunctional SOD1 protein may also positively influence motor neuron survival.

- Inducers of intraaxonal transport. Molecules that signal damage in the bouton terminal are transported to the neuronal soma. In ALS, this transport is retricted, thus the damage information reaches the peri-nuclear area only delayed.

- Drugs supporting nerve-muscle transmission. Defects in the transmission at the neuromuscular junction may contribute to disease progress.

- Stabilizers of the neuro-vascular unit. The loss of proteins at the tight junctions may disrupt the neuro-vascular unit. Thus molecules stabilizing the tight junctions may ameliorate the supply of neurons with substrates.

- Anti-inflammatory compounds. Neuroinflammation plays a role in the chronic detrimental processes occurring in the immediate microenvironment of the neuron.

- Neuroprotectants. Since neurodegeneration is the general mechanism in ALS progression, neuroprotective drugs may prevent or slow down neuronal breakdown.

- Anti-apoptotic compounds. Cell death is the ultimate reason in the apoptotic cascade. Thus compounds preventing cell death may contribute to increased survival of motor neurons.

- Growth factors. Growth factors such as G-CSF, VEGF, GDNF and others can both stimulate the growth of novel neurons (neurogenesis) and the repair of damaged neurons (neuroregeneration).

- Various techniques whereby muscles can be strengthened even in an environment where motor neurons are degenerating, thus maintaining motor function.

- Gene therapy. In these approaches, the expression of endogenous proteins, such as growth factors, are used to increase

- Stem cell therapies. The transplantation of various sources, such as bone-marrow derived stem cells (BMSC), mesenchymal stem cells (MSC), or neuronal stem cells (NSC), may support the microenvironment and thus the survival of motor neurons, or supply new motor neurons by replacing apoptotic cells. 


\section{Clinical trials in ALS}

\subsection{Programmed failure in clinical trials for ALS?}

In the typical process of drug development, preclinical data such as biochemical assays, cellular assays, and rodent models for the disease, lead to positive results with regard to predefined outcome parameters, for example, the increase in muscle strength, or survival time. For all of the drugs listed in the next section, promising preclinical data have been provided and published (for review, see (Ludolph \& Sperfeld, 2005)). But why did the majority of the clinical trials fail, when preclinical data have been so promising?

Three major points came to my notice, when reviewing the literature: First, the animal models (mouse, rat, drosophila etc.) may either not sufficiently reflect the human pathology, or the animal pathology does not reflect human conditions (discussed in Green, 2002; Kiernan et al., 2011; Scott et al., 2008). Second, "ALS" is a clinical but not a pathophysiological entity. Thus, the inter-personal variability between patients is too big, and the inclusion criteria are too broad. Third, the design of the clinical trials may be insufficient (Aggarwal \& Cudkowicz, 2008; Fornai et al., 2011; Kiernan et al., 2011; Maragakis, 2009), including:

- the number of subjects is too small,

- the time for follow-up is too short,

- the power of the study is calculated too low,

- the inclusion criteria are too broad,

- the outcome measures are not well-defined and comparable, or insufficient.

In future clinical trials, these issues should be discussed and included into the design of clinical ALS trials (Borasio, 1997).

\subsection{Consensus guidelines for ALS trials}

Therefore, a round table has been established to agree on minimal criteria for a "good" clinical trial (Miller et al., 1999). Of note, there have been substantial efforts also in other diseases such as stroke research to agree on clinical and pre-clinical guidelines for research, such as the "Stroke Therapy Academic Industry Roundtable (STAIR)" (STAIR - Stroke Treatment Academic Industry Roundtable, 2006).

In the following paragraphs, I will shortly summarize the consensus guidelines for ALS trial. The prerequisite for any ALS trial should be a substantial diagnosis according to the criteria defined by the World Federation of Neurology (see above). Moreover, the inclusion criteria should be handled strictly, including that both sporadic and familial ALS can be entered into the trial. The age of the patients should be limited between 18 and 85 years of age. Symptoms should show a disease progression within the first six months after onset, but not more than five years. Additionally, also exclusion criteria have been defined, for example, the patients should not show sensory abnormalities, dementia, other neurological diseases, they should not suffer from any uncompensated medical illness, substance abuse, or psychiatric illness. Of note, the patients should not be taking any other investigational drug.

The endpoints of the trial must be defined in advance, for example, survival time, muscle strength, or ventilator dependence are common endpoints. All trials should include a control group.

The quality of life should be assessed in every efficacy trial. The statistical analysis must be sound and planned with sufficient power. Any co-medication must be carefully reconsidered. 
Since there has been an early release of information about the efficacy in clinical ALS trials, which had to be revoked after thorough analysis, any information with regard to the efficacy of an investigational drug should only be released when peer-reviewed publication is at least imminent (with the exception of scientific meetings). The investigator is responsible for any conflict of interest.

The design of ALS trials should comprehend three phases (Brooks, 1997). In phase I, toxicity and pharmacokinetics is tested. In phase II (pilot, exploratory, or screening trials) information is gathered about dose finding, preliminary efficacy, and further safety observations. In phase III, definitive efficacy and safety is evaluated. Phase I trials should incorporate a placebo control group and the follow-up should be at least six months. Phase II trials may use placebo controls, historic controls, or a crossover design. If the prospective therapeutic value aims at improvement of signs and symptoms, such as increased muscle strength or ameliorated function, the follow-up should be at least six months, whereas trials aiming at stabilization or slowing of deterioration should observe the patients' condition for at least 12 months (Bedlack, 2010). All phase III trials should be placebo-controlled. The endpoints should include at least the survival time, assessment of strength measured by maximum voluntary isometric contraction, pulmonary function, and functional performance by the ALS rating scale. Of course, an independent data and safety monitoring board should be established.

Of note, since survival times are rather short, many patients feel desperate and take unapproved medication out of the reach of a clinical trial. By establishing these consensus guidelines, this potentially dangerous drug use may be reduced (Ross, 2009).

\subsection{Overview over drug candidates in clinical ALS trials}

In the following "inventory" of clinical trials in ALS, I will give an overview over drug candidates used in ALS trials. I have included all interventional clinical trials registered at Clinicaltrials.gov (http://clinicaltrials.gov/). Information on these trials can be obtained by accessing the website http://ClinicalTrials.gov/show/NCTxxx, where $x x x$ stands for the registration number shown below.

Since there have been various clinical trials in the era before Clinicaltrials.gov required registration, and before a consensus conference established criteria for ALS trials (Miller et al., 1999), I have included some information on earlier trials. On the other hand, I excluded case reports, trials with nutritional supplements, and non-pharmacological therapeutic procedures such as plasma exchange, whole-body irridation, hyperbaric oxygenation, balneotherapy, cervico-dorsal electroshock therapy, adrenal cortex injection or stem cell injection, even when the stem cells are used as vehicles and vectors for the expression of biologicals.

Of note, this inventory is neither comprehensive, nor does it contain all available references due to space restriction. It is mainly based on a selective literature search in the PubMed database, and summarizes recent reviews in the field (Carlesi et al., 2011; Miller et al., 2005; Siciliano et al., 2010; Zinman \& Cudkowicz, 2011; Zoccolella et al., 2009).

\subsection{1 $\mathrm{N}$-acetylcysteine}

The anti-oxidant $\mathrm{N}$-acetylcysteine did not show efficacy in a phase II clinical trial (Louwerse et al., 1995). 


\subsubsection{AEOL-10150}

AEOL-10150 is a metalloporphyrin scavenging reactive oxygen species (ROS) (Orrell, 2006). It has been tested for safety and tolerability in three phase I trials, but further development has been halted.

\subsubsection{Amantadine (1-adamantylamine, 1-aminoadamantane)}

Amantadine shows a weak NMDA receptor antagonism and anti-cholinergic effects. In a cross-over study with guanidine, no benefits for ALS patients have been described (Munsat et al., 1981).

\subsubsection{Anakinra}

Anakinra is a recombinant antibody directed against the interleukin-1 receptor (IL-1R). IL-1 is involved in sustaining the neuroinflammatory process. Treatment with anakinra in the G93A-SOD1 transgenic mouse model of ALS extended the lifespan of the animals and decreased neuroinflammation (Meissner et al., 2010). Thus blocking of the IL-1R may be a potential target in decreasing the speed of ALS progression (van der Meer \& Simon, 2010). Currently, a phase II study (NCT01277315), designed as a riluzole add-on study, investigates the safety and tolerability of anakinra in ALS.

\subsubsection{Antioxidants}

In a systematic review, no evidence for a benefit of anti-oxidant treatment with regard to survival, neither alone, nor in combination, has been described (Orrell et al., 2008). The antioxidants administered in ALS patients included vitamin E, acetylcysteine, L-methionine, and selenium.

\subsubsection{Arimoclomol (BRX-220)}

The small molecule arimoclomol is a co-inducer of heat-shock proteins (Phukan, 2010), namely of HSP70 (Brown, 2007). Thus it may be used to increase endogenous cellular protein repair and to prevent misfolding, or aggregation, of proteins by activating molecular chaperones (Kalmar \& Greensmith, 2009).

Arimoclomol was tested in two phase II studies to evaluate safety and efficacy in ALS patients (NCT00561366) and to find a dose range and to determine pharmacokinetic parameters (NCT00244244) (Cudkowicz et al., 2008; Lanka et al., 2009).

Currently, arimoclomol is tested in a phase II/III trial in patients with SOD1-positive fALS (NCT00706147).

\subsubsection{Arundic acid (ONO-2506)}

Arundic acid is an enantiomeric, three carbon atom homolog of valproic acid, with antiinflammatory and anti-glutamatergic effects (de Paulis, 2003).

It was tested in two phase II studies, designed as riluzole add-on, in clinical ALS trials for long-term safety (NCT00694941) and safety and efficacy (NCT00403104). The original evaluation of the trials did not show statistically significant differences between groups, but the subgroup analysis showed a possible positive effect for patients in early stages, namely within 14 months after onset of symptoms. On the other hand, patients with longer disease onset showed negative outcome (Thomas Meyer, 2005). 


\subsubsection{AVP-923 (Zenvia)}

AVP-923 is a combinational formulation containing dextromethorphan hydrobromide, which is an NMDA antagonist and sigma-1 receptor agonist, and quinidine sulphate, which inhibits the cytochrome P450 2D6 (CYP2D6) enzyme. Dextromethorphan hydrobromide shows a high first pass metabolism in the liver, where it is metabolized by CYP2D6. Thus the addition of quinidine sulphate increases the bioavailability of dextromethorphan hydrobromide (Olney \& Rosen, 2010).

AVP-923 was tested in two phase III trials in ALS patients with pseudobulbar affect (PBA), which is characterized by emotional dysregulation, such as uncontrollable outbursts of laughing or crying that are inappropriate to the emotions being experienced (Garnock-Jones, 2011; Olney \& Rosen, 2010). The study showed that AVP-923 ameliorates symptoms of PBA in ALS patients and improved quality of life and quality of relationships (Brooks et al., 2004).

\subsubsection{Azathioprine}

The immunosuppressant azathioprine in combination with prednisolone did not show a benefit in ALS patients (Werdelin et al., 1990).

\subsubsection{Brain-derived neurotrophic factor (BDNF)}

The neuroprotective growth factor BDNF has been evaluated in a phase I/II clinical trial which reported a trend for prolonged survival after subcutaneous infusion (The BDNF Study Group \& Bradley, 1995), a result which could not be reproduced in the subsequent phase III clinical trial (The BDNF Study Group (Phase III), 1999). The intrathecal administration was safe and well-tolerated (Ochs et al., 2000).

\subsubsection{Branched-chain amino acids (BCAA)}

The branched-chain amino acids comprehend leucine, isoleucine, and valine.

In clinical trials, branched chain amino acids did not show a beneficial effect in ALS patients (Tandan et al., 1996).

\subsubsection{Bromocriptine}

The dopamine agonist bromocriptine did not show a benefit in ALS patients (SzulcKuberska et al., 1990).

\subsubsection{Buspirone}

The anxiolytic agent buspirone did not show a benefit in ALS patients (The ALS Association, 2010).

\subsubsection{Ceftriaxone}

Ceftriaxone is a B-lactam antibiotic which also shows anti-oxidant and anti-excitotoxity effects (Traynor et al., 2006).

Currently, ceftriaxone is evaluated in a phase III clinical trial in patients with ALS (NCT00349622).

\subsubsection{Celecoxib}

Celecoxib is an inhibitor of cyclooxygenase-2 (COX-2), an enzyme which promotes inflammation by releasing of inflammatory substances, such as prostaglandin E(2) (PGE2). 
The rationale of celecoxib treatment is the reduction of PGE2 in the cerebrospinal fluid (CSF), thus preventing neuroinflammation and neuronal loss.

In a phase II clinical trial (NCT00355576), celecoxib did not show a beneficial effect on the decline in muscle strength, motor unit number estimates, vital capacity, ALS Functional Rating Scale-Revised, and overall survival (Cudkowicz et al., 2006). Moreover, PGE2 levels in the CSF were not elevated at baseline and did not decline during treatment (Cudkowicz et al., 2006). In this trial, celecoxib was combined with creatinine and/or minocycline (Gordon et al., 2008).

\subsubsection{Ciclosporine A}

The immunosuppressant cyclosporine A did not show a benefit in ALS patients (Appel et al., 1988).

\subsubsection{Ciliary neurotrophic factor (CNTF)}

CNTF is a neurotrophic factor with neuroprotective properties.

It has been tested in two clinical trials finding no effect on disease progression (ALS CNTF Treatment Study Group, 1996; Miller et al., 1996), but an increased trend of adverse effects (Miller et al., 1996).

\subsubsection{Cistanche total glycosides (CTGs)}

The glycosidic extract of the plant Cistanche spp. has a long tradition in its medicinally use in Traditional Chinese Medicine (TCM). It has been described as a neuroprotective agent in a mouse model of Parkinson's Disease (PD) (Li et al., 2008). Currently, Cistanche Total Glycosides are investigated in a phase II trial (NCT00753571). Of note, the CTGs are the only agents in registered ALS trials without a defined chemical composition, which may impose problems in future comparability to other medications and effectiveness of different preparations.

\subsubsection{CK-2017357}

With regard to the loss of skeletal muscle strength, the substituted urea derivative CK2017357 is claimed to activate the muscle protein troponin in fast skeletal muscle fibres. A proposed mode-of-action is sensitizing the sarcomere to calcium, thus the neuro-muscular transmission is amplified, thus muscle power increases and the time to musclular fatigue is delayed (von Haehling et al., 2010).

A phase IIa study (NCT01089010) was completed in 2010 and showed a trend towards short-term improvements in grip-strength and respiration parameters.

\subsubsection{Coenzyme Q10}

Coenzyme Q10 has been proposed to inhibit neurodegeneration. In a phase II clinical trial, it was well tolerated and safe (Ferrante et al., 2005), but showed no efficacy in a phase II futility trial (NCT00243932) (Kaufmann et al., 2009; Levy et al., 2006).

\subsubsection{Creatine}

Creatine acts as anti-oxidant and is a mitochondrial co-factor.

It has been evaluated in several phase II clinical trials (NCT00070993, NCT00005674, NCT00005766) which reported no beneficial effect in ALS patients (Groeneveld et al., 2003; Shefner et al., 2004), as well as a phase III clinical trial (NCT00069186) (Rosenfeld et al., 2008). 
Creatine supplementation temporarily increased maximal isometric power in ALS patients (Mazzini et al., 2001).

In a phase I dose-escalation trial, creatine concentrations in the brain increased after oral administration (Atassi et al., 2010).

Currently, creatine is evaluated in a phase II clinical trial (NCT01257581) in combination with tamoxifen in ALS patients.

\subsubsection{Cyclophosphamide}

The immunosuppressant cyclophosphamide showed only a temporary amelioration of symptoms in ALS patients without a long-term benefit (Gourie-Devi et al., 1997).

\subsubsection{Dexpramipexole (R-(+) pramipexole; RPPX; KNS-760704)}

Dexpramipexole is a synthetic amino-benzothiazole and the (+)-enantiomer of pramipexole which has dopaminergic activity and is a mitochondrial neuroprotectant by scavenging reactive oxygen and nitrogen species (RONS) (Cheah \& Kiernan, 2010; Gribkoff \& Bozik, 2008).

In earlier studies, RPPX reduced oxidative stress in sporadic ALS patients (Pattee et al., 2003). RPPX has been found to be safe and tolerable (Bozik et al., 2010; Wang et al., 2008), but did not change ALSFRS-R (NCT00140218, NCT00600873, NCT00596115, NCT00647296) (Wang et al., 2008). In the open-label extension protocol, RPPX caused a non-significant reduction in the slope of decline in the ALSFRS-R score (NCT00931944) (Wang et al., 2008).

RPPX is currently evaluated in a phase III study (NCT01281189) in ALS patients.

\subsubsection{3,4-Diaminopyridine (DAP)}

The potassium channel blocker DAP did not show a benefit in ALS patients (Aisen et al., 1996; Aisen et al., 1995). Currently, the drug is re-evaluated after a phase I safety study (Bertorini et al., 2011).

\subsubsection{Dronabinol}

Dronabinol is a synthetic $\Delta$ 9-tetrahydrocannabinol (Delta-9-THC, $\triangle 9$-THC, THC).

It has been tested in a phase II study (NCT00812851) in ALS patients suffering from muscular cramps, where no subjective improvement of cramp intensity has been seen (Weber et al., 2010).

\subsubsection{Edaravone (MCl-186; NSC 2629)}

Edavarone is an anti-oxidant free radical scavenger (Takahashi, 2009).

It has been tested in several phase II/III clinical trials (NCT00330681, NCT00415519, NCT00424463) for safety and efficacy. A phase II study found a possible delay in the progression of functional motor symptoms in ALS patients (Yoshino \& Kimura, 2006).

\subsubsection{Erythropoietin (EPO)}

EPO is a hematopoietic growth factor with neuroprotective properties (Maurer et al., 2008). Moreover, EPO exhibited anti-inflammatory and anti-apoptotic effects.

It has been evaluated in a phase II trial, finding no effects on survival and functional outcome (Lauria et al., 2009). 


\subsubsection{Escitalopram}

Escitalopram is a selective serotonin reuptake inhibitor (SSRI) and used clinically as an antidepressant.

It has been tested in a phase III clinical trial (NCT00965497) for the improvement of depressive symptoms and the quality of life in ALS patients.

\subsubsection{Gabapentin}

Gabapentin is an anti-convulsant with anti-glutamatergic effects, which have been proposed to slow down neuronal pathology (Welty et al., 1995).

It has been tested in a phase II trial finding a smaller slope in arm strength decrase (Miller et al., 1996), but a subsequent phase III trial has not shown beneficial effects of (Miller et al., 2001). No effects on neuronal integrity have been found in an MR spectroscopy study (Kalra et al., 2003).

\subsubsection{Gangliosides}

Gangliosides are derivatives of sialylated glycosphingolipids containing one to five sialic acids at various anomeric linkage sites to the core glycan. They modulate the effect of nerve growth factor and activate protein kinase (DeFelice \& Ellenberg, 1984; Rapport, 1990).

Gangliosides have been tested in several clinical trials without benefit for ALS patients (Bradley et al., 1984; Harrington et al., 1984; Lacomblez et al., 1989).

\subsubsection{Glatiramer acetate}

Glatiramer acetate is a random polymer composed of four amino acids that are found in myelin basic protein (MBP). It has been proposed that it inhibits neuroinflammation, stimulates anti-glutamatergic growth factor effects.

In a phase II clinical trial (NCT00326625), glatiramer acetate has not shown any beneficial effect in ALS patients (Meininger et al., 2009).

\subsubsection{Granulocyte colony stimulating Factor (G-CSF; AX200)}

G-CSF is a hematopoietic growth and maturation factor with neuroprotective and neuroregenerative effects (reviewed in Maurer et al., 2008).

G-CSF has been evaluated in a phase II study (NCT00298597) in ALS patients, finding no differences with regard to functional outcome between study groups, but slowing the progression of white matter tract destruction (Duning et al., 2011). In a second phase II trial (NCT00397423), the authors reported preliminary data on 13 patients with slower disease progression (Zhang et al., 2009). Another clinical trial did not report statistically significant differences between study and control group (Nefussy et al.), but a trend towards slowing down disease progression.

\subsubsection{Growth hormone (GH, Somatropin)}

Human growth hormone $(\mathrm{hGH})$ stimulates the production and release of insulin-like growth factor I (IGF-1) which induces cell proliferation and differentiation (Rosenbloom, 2009).

GH has evaluated in a phase II trial (NCT00635960) with no effects on disease progression (Sacca et al., 2011). 


\subsubsection{GSK1223249}

GSK1223249 is a humanised monoclonal antibody which counteracts the inhibition of neurite outgrowth by Nogo-A. Currently, GSK1223249 is evaluated in a phase I study (NCT00875446) for safety in ALS patients.

\subsubsection{Guanidine}

In a clinical trial, guanidine caused severe side effects such as acute paralysis (Norris et al., 1974; Norris et al., 1974). In a cross-over study with amantadine, no benefits for ALS patients have been described (Munsat et al., 1981).

\subsubsection{Indinavir}

The antiviral drug indinavir did not show a benefit in ALS patients (Scelsa et al., 2005).

\subsubsection{Insulin-like growth factor-1 (IGF-1)}

IGF-1 is a growth factor stimulated by the human growth hormone (hGH). It induces cell proliferation and differentiation (Rosenbloom, 2009).

Whereas a first trial of IGF-1 in ALS patients reported a slower disease progression of functional impairment and a higher quality of life score (Lai et al., 1997), a subsequent study did not find beneficial effects after 9 months of treatment (Borasio et al., 1998). A phase III clinical trial (NCT00035815) found no beneficial effects after 2 years of treatment in ALS patients (Sorenson et al., 2008).

\subsubsection{Interferon}

The immunomodulators interferon-alpha (Dalakas et al., 1986; Mora et al., 1986) and interferon-beta (Beghi et al., 2000; Bouche et al., 1986) did not show a benefit in ALS patients.

\subsubsection{ISIS 333611 (ISIS-SOD1 $1_{\mathrm{Rx}}$ )}

ISIS 333611 is an antisense oligonucleotide inhibitor of $\mathrm{Cu} / \mathrm{Zn}$ superoxide dismutase (SOD1) (Smith et al., 2006). Currently, a phase I (NCT01041222) investigates the safety, tolerability, and activity familial ALS caused by SOD1 gene mutations.

\subsubsection{Isoprinosine}

The antiviral drug isoprinosine did not show a benefit in ALS patients (Fareed \& Tyler, 1971; Percy et al., 1971).

\subsubsection{Lamotrigine}

Lamotrigine is an anti-epileptic drug with anti-excitotocicity effects. It has been tested in two clinical trials (Eisen et al., 1993; Ryberg et al., 2003) showing no effects on disease progression.

\subsubsection{Lecithin}

The term lecithin describes a group compounds consisting of phosphoric acid, choline, fatty acids, glycerol, glycolipids, triglycerides, and phospholipids. Typical members comprehend phosphatidylcholine, phosphatidylethanolamine, and phosphatidylinositol.

In a clinical trial, lecithin did not show a benefit in ALS patients (Kelemen et al., 1982). 


\subsubsection{Leuprorelin (Leuprolide)}

Leuprorelin is a is a nonapeptide and a GnRH analog.

It has been tested in a phase II study in combination with testosterone (NCT00004771), the results are awaited.

\subsubsection{Levamisole}

Levamisole is a synthetic imidazothiazole derivative with anti-helmintic and immunomodulatory effects. In a clinical trial, no beneficial effects have been seen for ALS patients (Olarte \& Shafer, 1985).

\subsubsection{Lithium}

Lithium has been described as inductor of autophagy and anti-oxidant. Clinically, it is used as mood stabilizer.

In a phase II study (EudraCT ), lithium did not show efficacy with regard to survival and keeping of patient autonomy (Chio et al.).

In another phase II study, lithium was reported to delay disease progression (Fornai et al., 2008), but in a follow-up, riluzole add-on phase II study (NCT00818389), lithium has been proven to be safe and well tolerated in ALS patients, but did not slow disease progression (Aggarwal et al.). Due to these findings, two other studies of lithium are currently not recruiting patients (NCT00925847, NCT00790582).

\subsubsection{Memantine}

Memantine non-competitive antagonist at the NMDA and AMPA glutamate receptors with low affinity.

In two phase II/III clinical trials (NCT01020331, NCT00409721), memantine was safe and tolerated, but no efficacy has been found in ALS patients (de Carvalho et al., 2010).

\subsubsection{Methylcobalamin (E0302, mecobalamin)}

Methylcobalamin is an analog of vitamin B12, which reduces the concentration of homocystein, an excitatory amino acid which showed toxic effects on motor neurons by inducing apoptosis.

ALS patients treated with high doses of methylcobalamin $(\mathrm{MeCbl})$ showed an increase in compound muscle action potential amplitudes (CMAPs) after 4 weeks of treatment (Kaji et al., 1998). It increased the decline in ALS patients with regard to becoming respirator-bound (Izumi \& Kaji, 2007).

Methylcobalamin is currently evaluated in two phase III studies (NCT00445172, NCT00444613) in ALS patients

\subsubsection{Minocycline}

Minocycline has been described as anti-apoptotic and anti-inflammatory.

In a phase III study (NCT00047723), minocycline showed harmful effects of minocycline in ALS patients (Gordon et al., 2007).

\subsubsection{Modafinil}

Modafinil is a psychostimulant clinically used for the treatment of narcolepsy and other sleep disorders. 
It is currently evaluated in a phase IV study (NCT00614926) for the treatment of fatigue in ALS patients.

\subsubsection{Naloxone}

The $\mu$ opioid receptor antagonist naloxone did not show a benefit in ALS patients (Silani et al., 1983).

\subsubsection{Neostigmine}

The cholinesterase inhibitor did not show a benefit in ALS patients (Aquilonius et al., 1986).

\subsubsection{Nimodipine}

The calcium channel antagonist nimodipine showed no beneficial effect in a clinical trail in ALS patients (Miller et al., 1996).

\subsubsection{NP001}

NP001 is a small molecule regulator of macrophage activation, which aims at restoring the neuroprotective state of macrophages, reducing inflammation, and normalizing the neuronal microenvironment.

NP001 has been tested in a phase I trial (NCT01091142) for safety and tolerability. It is currently evaluated in a subsequent phase II clinical trial (NCT01281631).

\subsubsection{Olanzapine}

Olanzapine is an atypic neuroleptic drug used in psychiatry for the treatment of schizophrenia and other psychoses. One of its effects is also weight gain. In ALS patients, an involuntary weight loss of more than 10 percent of the original body weight correlates with an increased mortality. Thus treatment with olanzapine might increase the body weight, or, at least, keep it constant.

Currently, olanzapine is evaluated in a phase II/III study (NCT00876772) in ALS patients.

\subsubsection{Olesoxime (TRO19622)}

Olesoxime is a neuroprotective agent with a cholesterol-like structure which is thought to act at the mitochondrial membrane (Bordet et al., 2010; Martin, 2010).

Currently, olesoxime is evaluated in a phase II/III trial (NCT00868166) as add-on to riluzole and a phase II/III safety extension study (NCT01285583).

\subsubsection{Penicillamine}

The metal ion chelating agent penicillamine did not show a benefit in ALS patients (Conradi et al., 1982).

\subsubsection{Pentoxifylline}

Pentoxifylline is an anti-apoptotic drug. It has been tested in a riluzole add-on phase II clinical trial, which did not show efficacy, but increased mortality (Meininger et al., 2006). 


\subsubsection{Phthalazine}

The inhibitor of cyclic adenosine monophosphate (cAMP) phosphodiesterase and cyclic guanine monophosphate (cGMP) phosphodiesterase phthalazinol did not show a benefit in ALS patients (Engel \& Brooks, 1980).

\subsubsection{Physostigmine}

The acetylcholine esterase inhibitor physostigmine did not show a benefit in ALS patients (Norris et al., 1993).

\subsubsection{Pioglitazone}

Pioglitazone activates the nuclear receptor peroxisome proliferator-activated receptor gamma (PPAR- $\gamma$ ) (Gillies \& Dunn, 2000; Kiaei, 2008). It has been used as anti-diabetic drug in diabetes type 2 .

In phase II clinical trial (NCT00690118), pioglitazone was found to be save and welltolerated, but showed no effect on ALS disease progression (Ludolph et al., 2010).

In a riluzole add-on phase II study (NCT00919555), pioglitazone is currently evaluated in combination with tretinoin.

\subsubsection{Prednisolone}

The immunosuppressant prednisolone in combination with azathioprine did not show a benefit in ALS patients (Werdelin et al., 1990).

\subsubsection{Pyrimethamine}

The anti-malaria drug pyrimethamine was found to reduce SOD1 levels in vitro and in vivo in rodents as well as in humans (Lange, 2008).

Pyrimethamine is currently evaluated in a phase I/II trial (NCT01083667) for tolerability, safety, and efficacy in familial ALS.

\subsubsection{Rasagiline}

Rasagiline is a monoamine oxidase type B inhibitor with neuroprotective effects.

Rasagiline is currently evaluated in a phase II clinical trial (NCT01232738).

\subsubsection{Riluzole}

Riluzole is an anti-glutamatergic drug (Cheah et al., 2010; R.G. Miller et al., 2007).

In two clinical trials, riluzole showed a moderate increase of about two months in survival after 21 and 18 months of treatment, respectively (Bensimon et al., 1994; Lacomblez et al., 1996). An open-label phase IV study (NCT00542412) found a longer survival in riluzoletreated patients of 92 days in median.

In subsequent population-based trials, older patients and patients with bulbar-onset had the biggest beneficial effect of riluzole, but the effects were transient and lost after longer periods of observation (Traynor et al., 2003; Zoccolella et al., 2007).

\subsubsection{SB-509}

SB-509 is an engeineered zinc finger protein which up-regulates the transcription of the proangiogenic vascular entothelial growth factor A (VEGF-A) (Liu et al., 2001), which is also neuroprotective and neuroregenerative (Maurer et al., 2008)

SB-509 is currently evaluated in a phase II clinical trial (NCT00748501). 


\subsubsection{Selegiline}

The anti-depressant drug selegiline is an inhibitor of monoamino oxidase B.

It has been tested in several clinical trials without benefit for ALS patients (Jossan et al., 1994; Lange et al., 1998; Mazzini et al., 1994).

\subsubsection{Snake venom}

Modified snake venom as neurotoxin did not show a benefit in ALS patients (Rivera et al., 1980).

\subsubsection{Sodium phenylbutyrate}

Sodium phenylbutyrate acts as a histone deacetylase inhibitor, therefore it improves transcription and stimulates post-transcriptional pathways.

In a phase II study (NCT00107770), sodium phenylbutyrate was safe and well tolerated (Cudkowicz et al., 2009).

\subsubsection{Sodium valproate}

Valproic acid (VPA) is a histone deacetylase inhibitor that showed antioxidative and antiapoptotic properties and reduced glutamate toxicity. It is used as antiepileptic drug.

In a phase II clinical trial (NCT00136110), VPA has been found safe but not effective with regard to survival and disease progression (Piepers et al., 2009).

\subsubsection{Talampanel (GYKI 53405)}

Talampanel is a derivated benzodiazepine which is a non-competitive antagonist at the AMPA glutamate receptor.

It has been evaluated in a phase II trial (NCT00982150) which showed safety and tolerability (Pascuzzi et al., 2010), whereas a subsequent phase II study (NCT00696332) did not show efficacy in ALS patients (reviewed in Carlesi et al., 2011).

\subsubsection{Tamoxifen}

The selective estrogen receptor modulator tamoxifen is an inhibitor of protein kinase C, which is a mediator in neuroinflammation.

It has been evaluated in a phase II study (NCT00214110) in ALS patients (Brooks et al., 2005) and was recommended for a phase III trial (mentioned in Traynor et al., 2006).

Currently, tamoxifen is evaluated in a phase II clinical trial (NCT01257581) in combination with creatine in ALS patients.

\subsubsection{Tauroursodeoxycholic acid (TUDCA)}

In preclinical data, tauroursodeoxycholic acid (TUDCA) has been found to be neuroprotective, antioxidative, and antiapoptotic in rat models of neurodegenerative diseases such as stroke (Rodrigues et al., 2002) and Huntington's disease (Keene et al., 2002). TUDCA is currently evaluated in a phase II study (NCT00877604) for safety and efficacy.

\subsubsection{TCH346}

$\mathrm{TCH} 346$ showed neuroprotective effects by binding glyceraldehydes-3-phosphate dehydrogenase (GAPDH) (Mück-Seler \& Pivac, 2000).

It has been evaluated in three phase II studies (NCT00230074, NCT00072709, NCT00036413), where it showed no beneficial effects in ALS (R. Miller et al., 2007). 


\subsubsection{Testosterone}

The sexual hormone testosterone has been tested in a phase II study in combination with leuprolide (NCT00004771), the results are awaited.

\subsubsection{Tetrahydroaminoacridine (Tacrine, THA)}

The reversible inhibitor of cholinesterase THA did not show a benefit in ALS patients (Askmark et al., 1990).

\subsubsection{Thalidomide}

Thalidomide is a small molecule which has been used as a sedative drug in the 1950s-1960s. Due to its teratogenic and neuropathic adverse effects, its use was discontinued until the 1990s, when thalidomide was introduced in oncology for its anti-angiogenic effects.

With regard to clinical trials in ALS, thalidomide was tested in a phase II clinical trial (NCT00140452) (Stommel et al., 2009), with no improvement in the ALS Functional Rating Scale (ALSFRS) and pulmonary function testing (PFT) curves after nine months of thalidomide treatment. Moreover, thalidomide showed severe side effects, and did not affect anti-inflammatory cytokine levels.

A second phase II clinical trial (NCT00231140) was terminated after severe adverse effects (Thomas Meyer, 2005).

\subsubsection{L-Threonine}

The hydroxylated essential amino acid L-threonine did not show a benefit in ALS patients (Blin et al., 1992; Tandan et al., 1996).

\subsubsection{Thyreotropin releasing hormone (TRH, Protirelin)}

TRH has been tested in a larger number of clinical trials, but none of them showed a benefit in ALS patients (Brooke et al., 1986; Brooks et al., 1987; Caroscio et al., 1986; Congia et al., 1991; Hawley et al., 1987; Imoto et al., 1984; Klimek et al., 1989; Klimek et al., 1988; Miller \& Warnick, 1989; Mitsumoto et al., 1986; Munsat et al., 1992; Patrignani et al., 1992; Serratrice et al., 1985; Stober et al., 1985; Thielen et al., 1987; Yamane et al., 1986).

\subsubsection{Tilorone}

The antiviral drug tilorone did not show a benefit in ALS patients (Olson et al., 1978).

\subsubsection{Tocopherol (Vitamin E)}

The anti-oxidant tocopherol has been evaluated in two phase II clinical trials, where tocopherol has been as add-on medication to riluzole in ALS patients. Both studies reported safe and well-tolerated drug administration, but no beneficial effect for ALS patients (Desnuelle et al., 2001; Graf et al., 2005). In a retrospective case-control study, high dosage of tocopherol decreased the risk of developing ALS (Veldink et al., 2007).

\subsubsection{Topiramate}

Topiramate is an anti-convulsant with anti-glutamatergic effects. It has been tested in a clinical trial without benefit for ALS patients, but with an increased rate of life-threatening side effects (Cudkowicz et al., 2003). 


\subsubsection{Transfer factor}

The antiviral agent transfer factor did not show a benefit in ALS patients (Jonas et al., 1979; Olarte et al., 1979).

\subsubsection{Tretinoin (all-trans retinoic acid)}

Tretinoin is the all-trans form of retinoic acid. It has various effects in the nervous system, including neuroprotection and neuroregeneration (for review, see (Lee et al., 2009)).

In a riluzole add-on phase II study (NCT00919555), tretinoin is currently evaluated in combination with pioglitazone.

\subsubsection{Trypan blue and trypan red}

The antimicrobial agents trypan blue and trypan red did not show a beneficial effect in ALS patients (Montanari \& Pessina, 1955; Schwob \& Bonduelle, 1952).

\subsubsection{Vascular endothelial growth factor (VEGF, sNN0029)}

VEGF is a neuroprotectice and angiogenic growth factor (Maurer et al., 2008). It is currently tested in a phase I/II clinical trial (NCT00800501) for safety and tolerability. Of note, VEGF must be administered into the CSF.

\subsubsection{Verapamil}

The calcium channel antagonist verapamil showed no beneficial effect in a clinical trail in ALS patients (Miller et al., 1996).

\subsubsection{Xaliproden (SR57746)}

The 5HT1R agonist xaliproden is neurotrophic and neuroprotective. It has been evaluated in phase II/III trials, which showed modest effects on vital capacity, but not on survival of ALS patients (Lacomblez et al., 2004; Meininger et al., 2004).

\subsubsection{YAM80}

There is no drug information available for YAM80 searching literature and chemical databases. YAM80 is evaluated in a phase II study (NCT00886977) for safety and efficacy in ALS patients.

\subsubsection{Zidovudine}

The antiviral drug zidovudine did not show a benefit in ALS patients (Westarp et al., 1993).

\subsubsection{Preclinical agents}

The following agents have shown promising results in preclinical assessment, but no clinical trials have been conducted:

Azathioprine, glycine, the tripeptide zVAD-fmk, AM-1241, celastrol, dantrolene, nordihydroguaiaretic acid, RO-28-2653, L-arginine, 5-hydroxytryptophan, $\mathrm{N}$-acetylated alphalinked acidic dipeptidase, mechano-growth factor (MGF), hepatocyte growth factor (HGF), glial-derived neurotrophic factor (GDNF), promethazine and other anti-histaminergic drugs, calcium disodium EDTA, toluloxy propane, ammonium tetramolybdate (for details, see (Mitsumoto, 2009; Zoccolella et al., 2007)), and cannabis (Carter et al., 2010). 


\subsubsection{1 "Alternative" therapeutic approaches}

Since most clinical trials in ALS did not show a benefit for ALS patients, a number of "alternative" or off-label cures have been propagated. Besides severe ethical issues, these treatments are of experimental nature, but not in the sense of a registered trial.

Some ALS patients who are desperately looking for a relief, tend to participate in these treatments, although they have to pay large amounts of money by themselves, and no proven, or replicable outcome has been reported in a peer-reviewed journal.

To evaluate some of these treatments, the ALSUntangled group (www.alsuntangled.com), which is based on social networking of patients, clinicians, and scientists (Bedlack \& Hardiman, 2009), reports sporadically on these treatments (see homepage for open and completed investigations).

\section{Outlook}

ALS remains a mysterious disease with a limited life expectancy and a deteriorating condition, although efforts in basic and clinical research brought some light in the understanding of pathophysiological aspects of MND.

With dozens of failed neuropharmacological trials in ALS, the current concept of the design of clinical trials in ALS patients must be reevaluated, as well as the pre-clinical models.

Future research may concentrate on the definition of ALS, maybe by the use of biomarkers, and on translational aspects, that is, how to transfer pre-clinical results into successful clinical treatment.

\section{Abbreviations}

ALS, amyotrophic lateral sclerosis ALSFRS, ALS functional rating scale

ALSSS, ALS severity scale

CNS, central nervous system

FTD, Fronto-Temporal Dementia

LMN, lower motor neuron

MND, motor neuron disease

PBP, progressive bulbar palsy

PLS, primary lateral sclerosis

PMA, progressive muscular atrophy

ROS, Reactive oxygen species

SOD1, [Zn, Cu] Superoxide dismutase type 1

$\mathrm{UMN}$, upper motor neuron

\section{Acknowledgments}

The author has been supported by grants of the European Union within the Framework Program 7, the Germany Ministry of Research and Education (BMBF) within the National Genome Research Network NGFN-2, the German Research Foundation DFG, the intramural program of the Medical Faculty of the University of Heidelberg, the Steuben-Schurz Society, and the Estate of Friedrich Fischer. 


\section{References}

Abrahams, S., Goldstein, L.H., Kew, J.J., Brooks, D.J., Lloyd, C.M., Frith, C.D. \& Leigh, P.N. (1996). Frontal lobe dysfunction in amyotrophic lateral sclerosis. A PET study. Brain, Vol. 119, No. Pt 6, pp. 2105-2120.

Aggarwal, S. \& Cudkowicz, M. (2008). ALS drug development: reflections from the past and a way forward. Neurotherapeutics, Vol. 5, No. 4, pp. 516-527.

Aggarwal, S.P., Zinman, L., Simpson, E., McKinley, J., Jackson, K.E., Pinto, H., Kaufman, P., Conwit, R.A., Schoenfeld, D., Shefner, J. \& Cudkowicz, M. (2010). Safety and efficacy of lithium in combination with riluzole for treatment of amyotrophic lateral sclerosis: a randomised, double-blind, placebo-controlled trial. Lancet Neurol, Vol. 9, No. 5, pp. 481-488.

Aisen, M.L., Sevilla, D., Edelstein, L. \& Blass, J. (1996). A double-blind placebo-controlled study of 3,4-diaminopyridine in amytrophic lateral sclerosis patients on a rehabilitation unit. J Neurol Sci, Vol. 138, No. 1-2, pp. 93-96.

Aisen, M.L., Sevilla, D., Gibson, G., Kutt, H., Blau, A., Edelstein, L., Hatch, J. \& Blass, J. (1995). 3,4-diaminopyridine as a treatment for amyotrophic lateral sclerosis. J Neurol Sci, Vol. 129, No. 1, pp. 21-24.

ALS CNTF Treatment Study Group. (1996). A double-blind placebo-controlled clinical trial of subcutaneous recombinant human ciliary neurotrophic factor (rHCNTF) in amyotrophic lateral sclerosis. . Neurology, Vol. 46, No. 5, pp. 1244-1249.

Appel, S.H., Stewart, S.S., Appel, V., Harati, Y., Mietlowski, W., Weiss, W. \& Belendiuk, G.W. (1988). A double-blind study of the effectiveness of cyclosporine in amyotrophic lateral sclerosis. Arch Neurol, Vol. 45, No. 4, pp. 381-386.

Appel, V., Stewart, S.S., Smith, G. \& Appel, S.H. (1987). A rating scale for amyotrophic lateral sclerosis: description and preliminary experience. Ann Neurol, Vol. 22, No. 3 , pp. 328-333.

Aquilonius, S.M., Askmark, H., Eckernas, S.A., Gillberg, P.G., Hilton-Brown, P., Rydin, E. \& Stalberg, E. (1986). Cholinesterase inhibitors lack therapeutic effect in amyotrophic lateral sclerosis. A controlled study of physostigmine versus neostigmine. Acta Neurol Scand, Vol. 73, No. 6, pp. 628-632.

Askmark, H., Aquilonius, S.M., Gillberg, P.G., Hartvig, P., Hilton-Brown, P., Lindstrom, B., Nilsson, D., Stalberg, E. \& Winkler, T. (1990). Functional and pharmacokinetic studies of tetrahydroaminoacridine in patients with amyotrophic lateral sclerosis. Acta Neurol Scand, Vol. 82, No. 4, pp. 253-258.

Atassi, N., Cook, A., Pineda, C.M., Yerramilli-Rao, P., Pulley, D. \& Cudkowicz, M. (2011). Depression in amyotrophic lateral sclerosis. Amyotroph Lateral Scler, Vol. 12, No. 2, pp. 109-112.

Atassi, N., Ratai, E.M., Greenblatt, D.J., Pulley, D., Zhao, Y., Bombardier, J., Wallace, S., Eckenrode, J., Cudkowicz, M. \& Dibernardo, A. (2010). A phase I, pharmacokinetic, dosage escalation study of creatine monohydrate in subjects with amyotrophic lateral sclerosis. Amyotroph Lateral Scler, Vol. 11, No. 6, pp. 508-513.

Averill, A.J., Kasarskis, E.J. \& Segerstrom, S.C. (2007). Psychological health in patients with amyotrophic lateral sclerosis. Amyotroph Lateral Scler, Vol. 8, No. 4, pp. 243-254.

Bedlack, R. \& Hardiman, O. (2009). ALSUntangled (ALSU): a scientific approach to off-label treatment options for people with ALS using tweets and twitters. Amyotroph Lateral Scler, Vol. 10, No. 3, pp. 129-130. 
Bedlack, R.S. (2010). Amyotrophic lateral sclerosis: current practice and future treatments. Curr Opin Neurol, Vol. 23, No. 5, pp. 524-529.

Bedlack, R.S., Traynor, B.J. \& Cudkowicz, M.E. (2007). Emerging disease-modifying therapies for the treatment of motor neuron disease/amyotropic lateral sclerosis. Expert Opin Emerg Drugs, Vol. 12, No. 2, pp. 229-252.

Beghi, E., Chio, A., Inghilleri, M., Mazzini, L., Micheli, A., Mora, G., Poloni, M., Riva, R., Serlenga, L., Testa, D. \& Tonali, P. (2000). A randomized controlled trial of recombinant interferon beta-1a in ALS. Italian Amyotrophic Lateral Sclerosis Study Group. Neurology, Vol. 54, No. 2, pp. 469-474.

Benatar, M. (2007). Lost in translation: treatment trials in the SOD1 mouse and in human ALS. Neurobiol Dis, Vol. 26, No. 1, pp. 1-13.

Bensimon, G., Lacomblez, L. \& Meininger, V. (1994). A controlled trial of riluzole in amyotrophic lateral sclerosis. ALS/Riluzole Study Group. N Engl J Med, Vol. 330, No. 9, pp. 585-591.

Bertorini, T.E., Rashed, H., Zeno, M., Tolley, E.A., Igarashi, M. \& Li, Y.D. (2011). Effects of 34 diaminopyridine (DAP) in motor neuron diseases. J Clin Neuromuscul Dis, Vol. 12, No. 3, pp. 129-137.

Blin, O., Pouget, J., Aubrespy, G., Guelton, C., Crevat, A. \& Serratrice, G. (1992). A doubleblind placebo-controlled trial of L-threonine in amyotrophic lateral sclerosis. $J$ Neurol, Vol. 239, No. 2, pp. 79-81.

Bogaert, E., d'Ydewalle, C. \& Van Den Bosch, L. (2011). Amyotrophic lateral sclerosis and excitotoxicity: from pathological mechanism to therapeutic target. CNS Neurol Disord Drug Targets, Vol. 9, No. 3, pp. 297-304.

Bohannon, R.W. \& Smith, M.B. (1987). Interrater reliability of a modified Ashworth scale of muscle spasticity. Phys Ther, Vol. 67, No. 2, pp. 206-207.

Borasio, G.D. (1997). Amyotrophic lateral sclerosis: lessons in trial design from recent trials. J Neurol Sci, Vol. 152 Suppl 1, No. 1, pp. S23-28.

Borasio, G.D., Robberecht, W., Leigh, P.N., Emile, J., Guiloff, R.J., Jerusalem, F., Silani, V., Vos, P.E., Wokke, J.H. \& Dobbins, T. (1998). A placebo-controlled trial of insulinlike growth factor-I in amyotrophic lateral sclerosis. European ALS/IGF-I Study Group. Neurology, Vol. 51, No. 2, pp. 583-586.

Bordet, T., Berna, P., Abitbol, J.-L. \& Pruss, R.M. (2010). Olesoxime (TRO19622): A Novel Mitochondrial-Targeted Neuroprotective Compound. Pharmaceuticals, Vol. 3, No. 2, pp. 345-368.

Bouche, P., Hanin, B. \& Castaigne, P. (1986). Effects of intrathecal interferon therapy in amyotrophic lateral sclerosis. Neurology, Vol. 36, No. 5, pp. 735-736.

Bozik, M.E., Mather, J.L., Kramer, W.G., Gribkoff, V.K. \& Ingersoll, E.W. (2010). Safety, Tolerability, and Pharmacokinetics of KNS-760704 (Dexpramipexole) in Healthy Adult Subjects. J Clin Pharmacol.

Bradley, W.G., Hedlund, W., Cooper, C., Desousa, G.J., Gabbai, A., Mora, J.S., Munsat, T.L. \& Scheife, R. (1984). A double-blind controlled trial of bovine brain gangliosides in amyotrophic lateral sclerosis. Neurology, Vol. 34, No. 8, pp. 1079-1082.

Brooke, M.H., Florence, J.M., Heller, S.L., Kaiser, K.K., Phillips, D., Gruber, A., Babcock, D. \& Miller, J.P. (1986). Controlled trial of thyrotropin releasing hormone in amyotrophic lateral sclerosis. Neurology, Vol. 36, No. 2, pp. 146-151.

Brooks, B., Sanjak, M., Roelke, K. \& al., e. (2005). Phase 2B randomized dose ranging clinical trial of tamoxifen, a selective estrogen receptor modulator [SERM], in ALS: 
sensitivity analyses of discordance between survival and functional outcomes with long-term follow-up. Amyotroph Lateral Scler Other Motor Neuron Disord, Vol. 6, No. Suppl 1, pp. 118.

Brooks, B.R. (1994). El Escorial World Federation of Neurology criteria for the diagnosis of amyotrophic lateral sclerosis. Subcommittee on Motor Neuron Diseases/Amyotrophic Lateral Sclerosis of the World Federation of Neurology Research Group on Neuromuscular Diseases and the El Escorial "Clinical limits of amyotrophic lateral sclerosis" workshop contributors. J Neurol Sci, Vol. 124 Suppl, pp. 96-107.

Brooks, B.R. (1997). Clinical evaluation of ALS drugs. Neurology, Vol. 48, No. Suppl 4, pp. S23-S27.

Brooks, B.R., Miller, R.G., Swash, M. \& Munsat, T.L. (2000). El Escorial revisited: revised criteria for the diagnosis of amyotrophic lateral sclerosis. Amyotroph Lateral Scler Other Motor Neuron Disord, Vol. 1, No. 5, pp. 293-299.

Brooks, B.R., Sufit, R.L., Montgomery, G.K., Beaulieu, D.A. \& Erickson, L.M. (1987). Intravenous thyrotropin-releasing hormone in patients with amyotrophic lateral sclerosis. Dose-response and randomized concurrent placebo-controlled pilot studies. Neurol Clin, Vol. 5, No. 1, pp. 143-158.

Brooks, B.R., Thisted, R.A., Appel, S.H., Bradley, W.G., Olney, R.K., Berg, J.E., Pope, L.E. \& Smith, R.A. (2004). Treatment of pseudobulbar affect in ALS with dextromethorphan/quinidine: a randomized trial. Neurology, Vol. 63, No. 8, pp. 1364-1370.

Brown, I.R. (2007). Heat shock proteins and protection of the nervous system. Ann N Y Acad Sci, Vol. 1113, pp. 147-158.

Bruijn, L.I., Miller, T.M. \& Cleveland, D.W. (2004). Unraveling the mechanisms involved in motor neuron degeneration in ALS. Annu Rev Neurosci, Vol. 27, pp. 723-749.

Burnstein, M.H. (1981). Familial amyotrophic lateral sclerosis, dementia, and psychosis. Psychosomatics, Vol. 22, No. 2, pp. 151-157.

Carlesi, C., Pasquali, L., Piazza, S., Lo Gerfo, A., Caldarazzo Ienco, E., Alessi, R., Fornai, F. \& Siciliano, G. (2011). Strategies for clinical approach to neurodegeneration in amyotrophic lateral sclerosis. Arch Ital Biol, Vol. 149, No. 1, pp. 151-167.

Caroscio, J.T., Cohen, J.A., Zawodniak, J., Takai, V., Shapiro, A., Blaustein, S., Mulvihill, M.N., Loucas, S.P., Gudesblatt, M., Rube, D. \& et al. (1986). A double-blind, placebo-controlled trial of TRH in amyotrophic lateral sclerosis. Neurology, Vol. 36, No. 2, pp. 141-145.

Carter, G.T., Abood, M.E., Aggarwal, S.K. \& Weiss, M.D. (2010). Cannabis and amyotrophic lateral sclerosis: hypothetical and practical applications, and a call for clinical trials. Am J Hosp Palliat Care, Vol. 27, No. 5, pp. 347-356.

Cedarbaum, J.M. \& Stambler, N. (1997). Performance of the Amyotrophic Lateral Sclerosis Functional Rating Scale (ALSFRS) in multicenter clinical trials. J Neurol Sci, Vol. 152 Suppl 1, pp. S1-9.

Cheah, B.C. \& Kiernan, M.C. (2010). Dexpramipexole, the R(+) enantiomer of pramipexole, for the potential treatment of amyotrophic lateral sclerosis. IDrugs, Vol. 13, No. 12, pp. 911-920.

Cheah, B.C., Vucic, S., Krishnan, A.V. \& Kiernan, M.C. (2010). Riluzole, neuroprotection and amyotrophic lateral sclerosis. Curr Med Chem, Vol. 17, No. 18, pp. 1942-1199. 
Chio, A., Borghero, G., Calvo, A., Capasso, M., Caponnetto, C., Corbo, M., Giannini, F., Logroscino, G., Mandrioli, J., Marcello, N., Mazzini, L., Moglia, C., Monsurro, M.R., Mora, G., Patti, F., Perini, M., Pietrini, V., Pisano, F., Pupillo, E., Sabatelli, M., Salvi, F., Silani, V., Simone, I.L., Soraru, G., Tola, M.R., Volanti, P. \& Beghi, E. (2010). Lithium carbonate in amyotrophic lateral sclerosis: lack of efficacy in a dose-finding trial. Neurology, Vol. 75, No. 7, pp. 619-625.

Colombrita, C., Onesto, E., Tiloca, C., Ticozzi, N., Silani, V. \& Ratti, A. (2011). RNA-binding proteins and RNA metabolism: a new scenario in the pathogenesis of Amyotrophic lateral sclerosis. Arch Ital Biol, Vol. 149, No. 1, pp. 83-99.

Congia, S., Tronci, S., Ledda, M., Porcella, A. \& Coppola, G. (1991). Low doses of TRH in amyotrophic lateral sclerosis and in other neurological diseases. Ital J Neurol Sci, Vol. 12, No. 2, pp. 193-198.

Conradi, S., Ronnevi, L.O., Nise, G. \& Vesterberg, O. (1982). Long-time penicillaminetreatment in amyotrophic lateral sclerosis with parallel determination of lead in blood, plasma and urine. Acta Neurol Scand, Vol. 65, No. 3, pp. 203-211.

Costa, J., Gomes, C. \& de Carvalho, M. (2010). Diagnosis, pathogenesis and therapeutic targets in amyotrophic lateral sclerosis. CNS Neurol Disord Drug Targets, Vol. 9, No. 6, pp. 764-778.

Cudkowicz, M., Qureshi, M. \& Shefner, J. (2004). Measures and markers in amyotrophic lateral sclerosis. NeuroRx, Vol. 1, No. 2, pp. 273-283.

Cudkowicz, M.E., Andres, P.L., Macdonald, S.A., Bedlack, R.S., Choudry, R., Brown, R.H., Jr., Zhang, H., Schoenfeld, D.A., Shefner, J., Matson, S., Matson, W.R. \& Ferrante, R.J. (2009). Phase 2 study of sodium phenylbutyrate in ALS. Amyotroph Lateral Scler, Vol. 10, No. 2, pp. 99-106.

Cudkowicz, M.E., Shefner, J.M., Schoenfeld, D.A., Brown, R.H., Jr., Johnson, H., Qureshi, M., Jacobs, M., Rothstein, J.D., Appel, S.H., Pascuzzi, R.M., Heiman-Patterson, T.D., Donofrio, P.D., David, W.S., Russell, J.A., Tandan, R., Pioro, E.P., Felice, K.J., Rosenfeld, J., Mandler, R.N., Sachs, G.M., Bradley, W.G., Raynor, E.M., Baquis, G.D., Belsh, J.M., Novella, S., Goldstein, J. \& Hulihan, J. (2003). A randomized, placebo-controlled trial of topiramate in amyotrophic lateral sclerosis. Neurology, Vol. 61, No. 4, pp. 456-464.

Cudkowicz, M.E., Shefner, J.M., Schoenfeld, D.A., Zhang, H., Andreasson, K.I., Rothstein, J.D. \& Drachman, D.B. (2006). Trial of celecoxib in amyotrophic lateral sclerosis. Ann Neurol, Vol. 60, No. 1, pp. 22-31.

Cudkowicz, M.E., Shefner, J.M., Simpson, E., Grasso, D., Yu, H., Zhang, H., Shui, A., Schoenfeld, D., Brown, R.H., Wieland, S. \& Barber, J.R. (2008). Arimoclomol at dosages up to $300 \mathrm{mg} /$ day is well tolerated and safe in amyotrophic lateral sclerosis. Muscle Nerve, Vol. 38, No. 1, pp. 837-844.

Dalakas, M.C., Aksamit, A.J., Madden, D.L. \& Sever, J.L. (1986). Administration of recombinant human leukocyte alpha 2-interferon in patients with amyotrophic lateral sclerosis. Arch Neurol, Vol. 43, No. 9, pp. 933-935.

de Carvalho, M., Dengler, R., Eisen, A., England, J.D., Kaji, R., Kimura, J., Mills, K., Mitsumoto, H., Nodera, H., Shefner, J. \& Swash, M. (2008). Electrodiagnostic criteria for diagnosis of ALS. Clin Neurophysiol, Vol. 119, No. 3, pp. 497-503.

de Carvalho, M., Pinto, S., Costa, J., Evangelista, T., Ohana, B. \& Pinto, A. (2010). A randomized, placebo-controlled trial of memantine for functional disability in amyotrophic lateral sclerosis. Amyotroph Lateral Scler, Vol. 11, No. 5, pp. 456-460. 
de Paulis, T. (2003). ONO-2506. Ono. Curr Opin Investig Drugs, Vol. 4, No. 7, pp. 863-867.

DeFelice, S.L. \& Ellenberg, M. (1984). Gangliosides--clinical overview. Adv Exp Med Biol, Vol. 174, pp. 625-628.

Desnuelle, C., Dib, M., Garrel, C. \& Favier, A. (2001). A double-blind, placebo-controlled randomized clinical trial of alpha-tocopherol (vitamin E) in the treatment of amyotrophic lateral sclerosis. ALS riluzole-tocopherol Study Group. Amyotroph Lateral Scler Other Motor Neuron Disord, Vol. 2, No. 1, pp. 9-18.

Duning, T., Schiffbauer, H., Warnecke, T., Mohammadi, S., Floel, A., Kolpatzik, K., Kugel, H., Schneider, A., Knecht, S., Deppe, M. \& Schabitz, W.R. (2011). G-CSF prevents the progression of structural disintegration of white matter tracts in amyotrophic lateral sclerosis: a pilot trial. PLoS One, Vol. 6, No. 3, pp. e17770.

Eisen, A., Stewart, H., Schulzer, M. \& Cameron, D. (1993). Anti-glutamate therapy in amyotrophic lateral sclerosis: a trial using lamotrigine. Can J Neurol Sci, Vol. 20, No. 4, pp. 297-301.

Eisen, A.A. (2007). Historical aspects of motor neuron diseases, In: Handbook of Clinical Neurology Motor Neuron Disorders and Related Diseases, Eisen, A.A. \& Shaw, P.J. (Eds.), pp. 1-11, Elsevier B.V., Amsterdam.

Engel, W.K. \& Brooks, B.R. (1980). Phthalazinol, thrombocytopenia, and amyotrophic lateral sclerosis. Arch Neurol, Vol. 37, No. 5, pp. 320.

Enns, M.W., Barakat, S.M. \& Brown, J.H. (1993). Amyotrophic lateral sclerosis presenting with psychosis. Psychosomatics, Vol. 34, No. 5, pp. 453-455.

Epton, J., Harris, R. \& Jenkinson, C. (2009). Quality of life in amyotrophic lateral sclerosis/motor neuron disease: a structured review. Amyotroph Lateral Scler, Vol. 10, No. 1, pp. 15-26.

Evdokimidis, I., Constantinidis, T.S., Gourtzelidis, P., Smyrnis, N., Zalonis, I., Zis, P.V., Andreadou, E. \& Papageorgiou, C. (2002). Frontal lobe dysfunction in amyotrophic lateral sclerosis. J Neurol Sci, Vol. 195, No. 1, pp. 25-33.

Fareed, G.C. \& Tyler, H.R. (1971). The use of isoprinosine in patients with amyotrophic lateral sclerosis. Neurology, Vol. 21, No. 9, pp. 937-940.

Ferentinos, P., Paparrigopoulos, T., Rentzos, M., Zouvelou, V., Alexakis, T. \& Evdokimidis, I. (2011). Prevalence of major depression in ALS: Comparison of a semi-structured interview and four self-report measures. Amyotroph Lateral Scler, Vol. 12, No. 4, pp. 297-302.

Ferguson, T.A. \& Elman, L.B. (2007). Clinical presentation and diagnosis of Amyotrophic Lateral Sclerosis. NeuroRehabilitation, Vol. 22, pp. 409-416.

Ferrante, K.L., Shefner, J., Zhang, H., Betensky, R., O'Brien, M., Yu, H., Fantasia, M., Taft, J., Beal, M.F., Traynor, B., Newhall, K., Donofrio, P., Caress, J., Ashburn, C., Freiberg, B., O'Neill, C., Paladenech, C., Walker, T., Pestronk, A., Abrams, B., Florence, J., Renna, R., Schierbecker, J., Malkus, B. \& Cudkowicz, M. (2005). Tolerance of highdose (3,000 mg/day) coenzyme Q10 in ALS. Neurology, Vol. 65, No. 1, pp. 18341836.

Foran, E. \& Trotti, D. (2009). Glutamate transporters and the excitotoxic path to motor neuron degeneration in amyotrophic lateral sclerosis. Antioxid Redox Signal, Vol. 11, No. 7, pp. 1587-1602.

Fornai, F., Longone, P., Cafaro, L., Kastsiuchenka, O., Ferrucci, M., Manca, M.L., Lazzeri, G., Spalloni, A., Bellio, N., Lenzi, P., Modugno, N., Siciliano, G., Isidoro, C., Murri, L., 
Ruggieri, S. \& Paparelli, A. (2008). Lithium delays progression of amyotrophic lateral sclerosis. Proc Natl Acad Sci U S A, Vol. 105, No. 6, pp. 2052-2057.

Fornai, F., Meininger, V. \& Silani, V. (2011). Future therapeutical strategies dictated by preclinical evidence in ALS. Arch Ital Biol, Vol. 149, No. 1, pp. 169-174.

Garnock-Jones, K.P. (2011). Dextromethorphan/Quinidine: in pseudobulbar affect. CNS Drugs, Vol. 25, No. 5, pp. 435-445.

Geser, F., Lee, V.M. \& Trojanowski, J.Q. (2010). Amyotrophic lateral sclerosis and frontotemporal lobar degeneration: a spectrum of TDP-43 proteinopathies. Neuropathology, Vol. 30, No. 2, pp. 103-112.

Geser, F., Martinez-Lage, M., Robinson, J., Uryu, K., Neumann, M., Brandmeir, N.J., Xie, S.X., Kwong, L.K., Elman, L., McCluskey, L., Clark, C.M., Malunda, J., Miller, B.L., Zimmerman, E.A., Qian, J., Van Deerlin, V., Grossman, M., Lee, V.M. \& Trojanowski, J.Q. (2009). Clinical and pathological continuum of multisystem TDP43 proteinopathies. Arch Neurol, Vol. 66, No. 2, pp. 180-189.

Gillies, P.S. \& Dunn, C.J. (2000). Pioglitazone. Drugs, Vol. 60, No. 2, pp. 333-343; discussion 344-335.

Giordana, M.T., Ferrero, P., Grifoni, S., Pellerino, A., Naldi, A. \& Montuschi, A. (2011). Dementia and cognitive impairment in amyotrophic lateral sclerosis: a review. Neurol Sci, Vol. 32, No. 1, pp. 9-16.

Gordon, P.H., Cheung, Y.K., Levin, B., Andrews, H., Doorish, C., Macarthur, R.B., Montes, J., Bednarz, K., Florence, J., Rowin, J., Boylan, K., Mozaffar, T., Tandan, R., Mitsumoto, H., Kelvin, E.A., Chapin, J., Bedlack, R., Rivner, M., McCluskey, L.F., Pestronk, A., Graves, M., Sorenson, E.J., Barohn, R.J., Belsh, J.M., Lou, J.S., Levine, T., Saperstein, D., Miller, R.G. \& Scelsa, S.N. (2008). A novel, efficient, randomized selection trial comparing combinations of drug therapy for ALS. Amyotroph Lateral Scler, Vol. 9, No. 4, pp. 212-222.

Gordon, P.H., Moore, D.H., Miller, R.G., Florence, J.M., Verheijde, J.L., Doorish, C., Hilton, J.F., Spitalny, G.M., MacArthur, R.B., Mitsumoto, H., Neville, H.E., Boylan, K., Mozaffar, T., Belsh, J.M., Ravits, J., Bedlack, R.S., Graves, M.C., McCluskey, L.F., Barohn, R.J. \& Tandan, R. (2007). Efficacy of minocycline in patients with amyotrophic lateral sclerosis: a phase III randomised trial. Lancet Neurol, Vol. 6, No. 12, pp. 1045-1053.

Gourie-Devi, M., Nalini, A. \& Subbakrishna, D.K. (1997). Temporary amelioration of symptoms with intravenous cyclophosphamide in amyotrophic lateral sclerosis. J Neurol Sci, Vol. 150, No. 2, pp. 167-172.

Graber, J.J. \& Dhib-Jalbut, S. (2009). Protective autoimmunity in the nervous system. Pharmacol Ther, Vol. 121, No. 2, pp. 147-159.

Graf, M., Ecker, D., Horowski, R., Kramer, B., Riederer, P., Gerlach, M., Hager, C., Ludolph, A.C., Becker, G., Osterhage, J., Jost, W.H., Schrank, B., Stein, C., Kostopulos, P., Lubik, S., Wekwerth, K., Dengler, R., Troeger, M., Wuerz, A., Hoge, A., Schrader, C., Schimke, N., Krampfl, K., Petri, S., Zierz, S., Eger, K., Neudecker, S., Traufeller, K., Sievert, M., Neundorfer, B. \& Hecht, M. (2005). High dose vitamin E therapy in amyotrophic lateral sclerosis as add-on therapy to riluzole: results of a placebocontrolled double-blind study. J Neural Transm, Vol. 112, No. 5, pp. 649-660.

Green, A.R. (2002). Why do neuroprotective drugs that are so promising in animals fail in the clinic? An industry perspective. Clin Exp Pharmacol Physiol, Vol. 29, No. 11, pp. 1030-1034. 
Gribkoff, V.K. \& Bozik, M.E. (2008). KNS-760704 [(6R)-4,5,6,7-tetrahydro-N6-propyl-2, 6benzothiazole-diamine dihydrochloride monohydrate] for the treatment of amyotrophic lateral sclerosis. CNS Neurosci Ther, Vol. 14, No. 3, pp. 215-226.

Groeneveld, G.J., Veldink, J.H., van der Tweel, I., Kalmijn, S., Beijer, C., de Visser, M., Wokke, J.H., Franssen, H. \& van den Berg, L.H. (2003). A randomized sequential trial of creatine in amyotrophic lateral sclerosis. Ann Neurol, Vol. 53, No. 4, pp. 437445 .

Harrington, H., Hallett, M. \& Tyler, H.R. (1984). Ganglioside therapy for amyotrophic lateral sclerosis: a double-blind controlled trial. Neurology, Vol. 34, No. 8, pp. 1083-1085.

Hawley, R.J., Kratz, R., Goodman, R.R., McCutchen, C.B., Sirdofsky, M. \& Hanson, P.A. (1987). Treatment of amyotrophic lateral sclerosis with the TRH analog DN-1417. Neurology, Vol. 37, No. 4, pp. 715-717.

Hetta, J. \& Jansson, I. (1997). Sleep in patients with amyotrophic lateral sclerosis. J Neurol, Vol. 244, No. 4 Suppl 1, pp. S7-9.

Hillel, A.D., Miller, R.M., Yorkston, K., McDonald, E., Norris, F.H. \& Konikow, N. (1989). Amyotrophic lateral sclerosis severity scale. Neuroepidemiology, Vol. 8, No. 3, pp. 142-150.

Holmoy, T. (2008). T cells in amyotrophic lateral sclerosis. Eur J Neurol, Vol. 15, No. 4, pp. 360-366.

Howland, R.H. (1990). Schizophrenia and amyotrophic lateral sclerosis. Compr Psychiatry, Vol. 31, No. 4, pp. 327-336.

Huey, E.D., Koppel, J., Armstrong, N., Grafman, J. \& Floeter, M.K. (2010). A pilot study of the prevalence of psychiatric disorders in PLS and ALS. Amyotroph Lateral Scler, Vol. 11, No. 3, pp. 293-297.

Ilieva, H., Polymenidou, M. \& Cleveland, D.W. (2009). Non-cell autonomous toxicity in neurodegenerative disorders: ALS and beyond. J Cell Biol, Vol. 187, No. 6, pp. 761772 .

Imoto, K., Saida, K., Iwamura, K., Saida, T. \& Nishitani, H. (1984). Amyotrophic lateral sclerosis: a double-blind crossover trial of thyrotropin-releasing hormone. J Neurol Neurosurg Psychiatry, Vol. 47, No. 12, pp. 1332-1334.

Izumi, Y. \& Kaji, R. (2007). [Clinical trials of ultra-high-dose methylcobalamin in ALS]. Brain Nerve, Vol. 59, No. 10, pp. 1141-1147.

Jackson, C.E. \& Bryan, W.W. (1998). Amyotrophic lateral sclerosis. Semin Neurol, Vol. 18, No. 1, pp. 27-39.

Jonas, S., Wichter, M. \& Spitler, L. (1979). Amyotrophic lateral sclerosis: failure of transfer factor therapy. Ann Neurol, Vol. 6, No. 1, pp. 84.

Jossan, S.S., Ekblom, J., Gudjonsson, O., Hagbarth, K.E. \& Aquilonius, S.M. (1994). Double blind cross over trial with deprenyl in amyotrophic lateral sclerosis. J Neural Transm Suppl, Vol. 41, pp. 237-241.

Kaji, R., Kodama, M., Imamura, A., Hashida, T., Kohara, N., Ishizu, M., Inui, K. \& Kimura, J. (1998). Effect of ultrahigh-dose methylcobalamin on compound muscle action potentials in amyotrophic lateral sclerosis: a double-blind controlled study. Muscle Nerve, Vol. 21, No. 12, pp. 1775-1778.

Kalmar, B. \& Greensmith, L. (2009). Activation of the heat shock response in a primary cellular model of motoneuron neurodegeneration-evidence for neuroprotective and neurotoxic effects. Cell Mol Biol Lett, Vol. 14, No. 2, pp. 319-335. 
Kalra, S., Cashman, N.R., Caramanos, Z., Genge, A. \& Arnold, D.L. (2003). Gabapentin therapy for amyotrophic lateral sclerosis: lack of improvement in neuronal integrity shown by MR spectroscopy. AJNR Am J Neuroradiol, Vol. 24, No. 3, pp. 476-480.

Kaufmann, P., Thompson, J.L., Levy, G., Buchsbaum, R., Shefner, J., Krivickas, L.S., Katz, J., Rollins, Y., Barohn, R.J., Jackson, C.E., Tiryaki, E., Lomen-Hoerth, C., Armon, C., Tandan, R., Rudnicki, S.A., Rezania, K., Sufit, R., Pestronk, A., Novella, S.P., Heiman-Patterson, T., Kasarskis, E.J., Pioro, E.P., Montes, J., Arbing, R., Vecchio, D., Barsdorf, A., Mitsumoto, H. \& Levin, B. (2009). Phase II trial of CoQ10 for ALS finds insufficient evidence to justify phase III. Ann Neurol, Vol. 66, No. 2, pp. 235244.

Kaur, C. \& Ling, E.A. (2008). Antioxidants and neuroprotection in the adult and developing central nervous system. Curr Med Chem, Vol. 15, No. 29, pp. 3068-3080.

Keene, C.D., Rodrigues, C.M., Eich, T., Chhabra, M.S., Steer, C.J. \& Low, W.C. (2002). Tauroursodeoxycholic acid, a bile acid, is neuroprotective in a transgenic animal model of Huntington's disease. Proc Natl Acad Sci U S A, Vol. 99, No. 16, pp. 1067110676.

Kelemen, J., Hedlund, W., Murray-Douglas, P. \& Munsat, T.L. (1982). Lecithin is not effective in amyotrophic lateral sclerosis. Neurology, Vol. 32, No. 3, pp. 315-316.

Kiaei, M. (2008). Peroxisome Proliferator-Activated Receptor-gamma in Amyotrophic Lateral Sclerosis and Huntington's Disease. PPAR Res, Vol. 2008, pp. 418765.

Kiernan, M.C., Vucic, S., Cheah, B.C., Turner, M.R., Eisen, A., Hardiman, O., Burrell, J.R. \& Zoing, M.C. (2011). Amyotrophic lateral sclerosis. Lancet, Vol. 377, No. 9769, pp. 942-955.

Klimek, A., Stepien, H. \& Szulc-Kuberska, J. (1989). [THyroliberin test in patients with amyotrophic lateral sclerosis]. Pol Tyg Lek, Vol. 44, No. 43-45, pp. 918-920.

Klimek, A., Szulc-Kuberska, J., Czernielewska-Rutkowska, I. \& Gluszcz-Zielinska, A. (1988). [Treatment of amyotrophic lateral sclerosis with TRH]. Neurol Neurochir Pol, Vol. 22, No. 3, pp. 206-210.

Kurt, A., Nijboer, F., Matuz, T. \& Kubler, A. (2007). Depression and anxiety in individuals with amyotrophic lateral sclerosis: epidemiology and management. CNS Drugs, Vol. 21, No. 4, pp. 279-291.

Lacomblez, L., Bensimon, G., Douillet, P., Doppler, V., Salachas, F. \& Meininger, V. (2004). Xaliproden in amyotrophic lateral sclerosis: early clinical trials. Amyotroph Lateral Scler Other Motor Neuron Disord, Vol. 5, No. 2, pp. 99-106.

Lacomblez, L., Bensimon, G., Leigh, P.N., Guillet, P. \& Meininger, V. (1996). Dose-ranging study of riluzole in amyotrophic lateral sclerosis. Amyotrophic Lateral Sclerosis/ Riluzole Study Group II. Lancet, Vol. 347, No. 9013, pp. 1425-1431.

Lacomblez, L., Bouche, P., Bensimon, G. \& Meininger, V. (1989). A double-blind, placebocontrolled trial of high doses of gangliosides in amyotrophic lateral sclerosis. Neurology, Vol. 39, No. 12, pp. 1635-1637.

Lai, E.C., Felice, K.J., Festoff, B.W., Gawel, M.J., Gelinas, D.F., Kratz, R., Murphy, M.F., Natter, H.M., Norris, F.H. \& Rudnicki, S.A. (1997). Effect of recombinant human insulin-like growth factor-I on progression of ALS. A placebo-controlled study. The North America ALS/IGF-I Study Group. Neurology, Vol. 49, No. 6, pp. 1621-1630.

Lange, D. (2008). Pyrimethamine as a therapy for SOD1 associated fALS: early findings. Amyotrophic Lateral Sclerosis, No. Suppl. 1, pp. 46. 
Lange, D.J., Murphy, P.L., Diamond, B., Appel, V., Lai, E.C., Younger, D.S. \& Appel, S.H. (1998). Selegiline is ineffective in a collaborative double-blind, placebo-controlled trial for treatment of amyotrophic lateral sclerosis. Arch Neurol, Vol. 55, No. 1, pp. 93-96.

Lanka, V., Wieland, S., Barber, J. \& Cudkowicz, M. (2009). Arimoclomol: a potential therapy under development for ALS. Expert Opin Investig Drugs, Vol. 18, No. 12, pp. 19071918.

Lauria, G., Campanella, A., Filippini, G., Martini, A., Penza, P., Maggi, L., Antozzi, C., Ciano, C., Beretta, P., Caldiroli, D., Ghelma, F., Ferrara, G., Ghezzi, P. \& Mantegazza, R. (2009). Erythropoietin in amyotrophic lateral sclerosis: a pilot, randomized, double-blind, placebo-controlled study of safety and tolerability. Amyotroph Lateral Scler, Vol. 10, No. 5-6, pp. 410-415.

Lee, H.P., Casadesus, G., Zhu, X., Lee, H.G., Perry, G., Smith, M.A., Gustaw-Rothenberg, K. \& Lerner, A. (2009). All-trans retinoic acid as a novel therapeutic strategy for Alzheimer's disease. Expert Rev Neurother, Vol. 9, No. 11, pp. 1615-1621.

Levy, G., Kaufmann, P., Buchsbaum, R., Montes, J., Barsdorf, A., Arbing, R., Battista, V., Zhou, X., Mitsumoto, H., Levin, B. \& Thompson, J.L. (2006). A two-stage design for a phase II clinical trial of coenzyme Q10 in ALS. Neurology, Vol. 66, No. 5, pp. 660663.

Li, W.W., Yang, R. \& Cai, D.F. (2008). [Protective effects of Cistanche total glycosides on dopaminergic neuron in substantia nigra of model mice of Parkinson's disease]. Zhongguo Zhong Xi Yi Jie He Za Zhi, Vol. 28, No. 3, pp. 248-251.

Lill, C.M., Abel, O., Bertram, L. \& Al-Chalabi, A. (2011). Keeping up with genetic discoveries in amyotrophic lateral sclerosis: The ALSoD and ALSGene databases. Amyotroph Lateral Scler, Vol. 12, No. 4, pp. 238-249.

Lillo, P. \& Hodges, J.R. (2009). Frontotemporal dementia and motor neurone disease: overlapping clinic-pathological disorders. J Clin Neurosci, Vol. 16, No. 9, pp. 11311135.

Lillo, P., Mioshi, E., Zoing, M.C., Kiernan, M.C. \& Hodges, J.R. (2011). How common are behavioural changes in amyotrophic lateral sclerosis? Amyotroph Lateral Scler, Vol. 12, No. 1, pp. 45-51.

Lipton, S.A., Gu, Z. \& Nakamura, T. (2007). Inflammatory mediators leading to protein misfolding and uncompetitive/fast off-rate drug therapy for neurodegenerative disorders. Int Rev Neurobiol, Vol. 82, pp. 1-27.

Liu, P.Q., Rebar, E.J., Zhang, L., Liu, Q., Jamieson, A.C., Liang, Y., Qi, H., Li, P.X., Chen, B., Mendel, M.C., Zhong, X., Lee, Y.L., Eisenberg, S.P., Spratt, S.K., Case, C.C. \& Wolffe, A.P. (2001). Regulation of an endogenous locus using a panel of designed zinc finger proteins targeted to accessible chromatin regions. Activation of vascular endothelial growth factor A. J Biol Chem, Vol. 276, No. 14, pp. 11323-11334.

Lou, J.S. (2008). Fatigue in amyotrophic lateral sclerosis. Phys Med Rehabil Clin N Am, Vol. 19, No. 3, pp. 533-543, ix.

Louwerse, E.S., Weverling, G.J., Bossuyt, P.M., Meyjes, F.E. \& de Jong, J.M. (1995). Randomized, double-blind, controlled trial of acetylcysteine in amyotrophic lateral sclerosis. Arch Neurol, Vol. 52, No. 6, pp. 559-564.

Ludolph, A.C., Kassubek, J., Meyer, T. \& Group, T.G.A.S. (2010). Phase II study of pioglitazone in ALS. Abstract Book of the 21st International Symposium on ALS/MND, pp. 45. 
Ludolph, A.C. \& Sperfeld, A.D. (2005). Preclinical trials--an update on translational research in ALS. Neurodegener Dis, Vol. 2, No. 3-4, pp. 215-219.

Maragakis, N.J. (2009). Rethinking a drug treatment failure on a traditional ALS target. Exp Neurol, Vol. 216, No. 2, pp. 254-257.

Martin, L.J. (2010). Olesoxime, a cholesterol-like neuroprotectant for the potential treatment of amyotrophic lateral sclerosis. IDrugs, Vol. 13, No. 8, pp. 568-580.

Maurer, M.H., Schabitz, W.R. \& Schneider, A. (2008). Old friends in new constellations--the hematopoetic growth factors G-CSF, GM-CSF, and EPO for the treatment of neurological diseases. Curr Med Chem, Vol. 15, No. 14, pp. 1407-1411.

Mazzini, L., Balzarini, C., Colombo, R., Mora, G., Pastore, I., De Ambrogio, R. \& Caligari, M. (2001). Effects of creatine supplementation on exercise performance and muscular strength in amyotrophic lateral sclerosis: preliminary results. J Neurol Sci, Vol. 191, No. 1-2, pp. 139-144.

Mazzini, L., Testa, D., Balzarini, C. \& Mora, G. (1994). An open-randomized clinical trial of selegiline in amyotrophic lateral sclerosis. J Neurol, Vol. 241, No. 4, pp. 223-227.

McGuire, D., Garrison, L., Armon, C., Barohn, R.J., Bryan, W.W., Miller, R., Parry, G.J., Petajan, J.H. \& Ross, M.A. (1997). A brief quality-of-life measure for ALS clinical trials based on a subset of items from the sickness impact profile. The SyntexSynergen ALS/CNTF Study Group. J Neurol Sci, Vol. 152 Suppl 1, No. 1, pp. S18-22.

McLeod, J.E. \& Clarke, D.M. (2007). A review of psychosocial aspects of motor neurone disease. J Neurol Sci, Vol. 258, No. 1-2, pp. 4-10.

Meininger, V., Asselain, B., Guillet, P., Leigh, P.N., Ludolph, A., Lacomblez, L., Robberecht, W. \& Pentoxifylline European Group. (2006). Pentoxifylline in ALS: a double-blind, randomized, multicenter, placebo-controlled trial. Neurology, Vol. 66, No. 1, pp. 8892.

Meininger, V., Bensimon, G., Bradley, W.R., Brooks, B., Douillet, P., Eisen, A.A., Lacomblez, L., Leigh, P.N. \& Robberecht, W. (2004). Efficacy and safety of xaliproden in amyotrophic lateral sclerosis: results of two phase III trials. Amyotroph Lateral Scler Other Motor Neuron Disord, Vol. 5, No. 2, pp. 107-117.

Meininger, V., Drory, V.E., Leigh, P.N., Ludolph, A., Robberecht, W. \& Silani, V. (2009). Glatiramer acetate has no impact on disease progression in ALS at $40 \mathrm{mg} /$ day: a double- blind, randomized, multicentre, placebo-controlled trial. Amyotroph Lateral Scler, Vol. 10, No. 5-6, pp. 378-383.

Meissner, F., Molawi, K. \& Zychlinsky, A. (2010). Mutant superoxide dismutase 1-induced IL-1beta accelerates ALS pathogenesis. Proc Natl Acad Sci U S A, Vol. 107, No. 29, pp. 13046-13050.

Miller, M.C. (2011). Commentary. Did Lou Gehrig have Lou Gehrig's disease? Harv Ment Health Lett, Vol. 27, No. 8, pp. 8.

Miller, R., Bradley, W., Cudkowicz, M., Hubble, J., Meininger, V., Mitsumoto, H., Moore, D., Pohlmann, H., Sauer, D., Silani, V., Strong, M., Swash, M. \& Vernotica, E. (2007). Phase II/III randomized trial of TCH346 in patients with ALS. Neurology, Vol. 69, No. 8, pp. 776-784.

Miller, R.G., Bryan, W.W., Dietz, M.A., Munsat, T.L., Petajan, J.H., Smith, S.A. \& Goodpasture, J.C. (1996). Toxicity and tolerability of recombinant human ciliary neurotrophic factor in patients with amyotrophic lateral sclerosis. Neurology, Vol. 47, No. 5, pp. 1329-1331. 
Miller, R.G., Gelinas, D. \& O'Connor, P. (2005). Amyotrophic lateral sclerosis Demos Medical Publishing, 1-932603-06-9, New York.

Miller, R.G., Mitchell, J.D., Lyon, M. \& Moore, D.H. (2007). Riluzole for amyotrophic lateral sclerosis (ALS)/motor neuron disease (MND). Cochrane Database Syst Rev, Vol. 24, No. 1, pp. CD001447.

Miller, R.G., Moore, D., Young, L.A., Armon, C., Barohn, R.J., Bromberg, M.B., Bryan, W.W., Gelinas, D.F., Mendoza, M.C., Neville, H.E., Parry, G.J., Petajan, J.H., Ravits, J.M., Ringel, S.P. \& Ross, M.A. (1996). Placebo-controlled trial of gabapentin in patients with amyotrophic lateral sclerosis. WALS Study Group. Western Amyotrophic Lateral Sclerosis Study Group. Neurology, Vol. 47, No. 6, pp. 1383-1388.

Miller, R.G., Moore, D.H., 2nd, Gelinas, D.F., Dronsky, V., Mendoza, M., Barohn, R.J., Bryan, W., Ravits, J., Yuen, E., Neville, H., Ringel, S., Bromberg, M., Petajan, J., Amato, A.A., Jackson, C., Johnson, W., Mandler, R., Bosch, P., Smith, B., Graves, M., Ross, M., Sorenson, E.J., Kelkar, P., Parry, G. \& Olney, R. (2001). Phase III randomized trial of gabapentin in patients with amyotrophic lateral sclerosis. Neurology, Vol. 56, No. 7, pp. 843-848.

Miller, R.G., Munsat, T.L., Swash, M. \& Brooks, B.R. (1999). Consensus guidelines for the design and implementation of clinical trials in ALS. World Federation of Neurology committee on Research. J Neurol Sci, Vol. 169, No. 1-2, pp. 2-12.

Miller, R.G., Petajan, J.H., Bryan, W.W., Armon, C., Barohn, R.J., Goodpasture, J.C., Hoagland, R.J., Parry, G.J., Ross, M.A. \& Stromatt, S.C. (1996). A placebo-controlled trial of recombinant human ciliary neurotrophic (rhCNTF) factor in amyotrophic lateral sclerosis. rhCNTF ALS Study Group. Ann Neurol, Vol. 39, No. 2, pp. 256-260.

Miller, R.G., Shepherd, R., Dao, H., Khramstov, A., Mendoza, M., Graves, J. \& Smith, S. (1996). Controlled trial of nimodipine in amyotrophic lateral sclerosis. Neuromuscul Disord, Vol. 6, No. 2, pp. 101-104.

Miller, R.G., Smith, S.A., Murphy, J.R., Brinkmann, J.R., Graves, J., Mendoza, M., Sands, M.L. \& Ringel, S.P. (1996). A clinical trial of verapamil in amyotrophic lateral sclerosis. Muscle Nerve, Vol. 19, No. 4, pp. 511-515.

Miller, S.C. \& Warnick, J.E. (1989). Protirelin (thyrotropin-releasing hormone) in amyotrophic lateral sclerosis. The role of androgens. . Arch Neurol, Vol. 46, No. 3, pp. 330-335.

Mitsumoto, H. (1997). Diagnosis and progression of ALS. Neurology, Vol. 48, No. S4, pp. 2S$8 \mathrm{~S}$.

Mitsumoto, H. (Eds.). (2009). Amyotrophic lateral sclerosis. A guide for patients and families. (3rd), Demos Medical Publishing, New York.

Mitsumoto, H., Przedborski, S. \& Gordon, P. (Eds.). (2006). Amyotrophic Lateral Sclerosis. Current Science and Approaches to Therapy Taylor \& Francis Group, 978-0-8247-29240 , New York.

Mitsumoto, H., Salgado, E.D., Negroski, D., Hanson, M.R., Salanga, V.D., Wilber, J.F., Wilbourn, A.J., Breuer, A.C. \& Leatherman, J. (1986). Amyotrophic lateral sclerosis: effects of acute intravenous and chronic subcutaneous administration of thyrotropin-releasing hormone in controlled trials. Neurology, Vol. 36, No. 2, pp. 152-159.

Montanari, M. \& Pessina, G. (1955). [Trypan red in therapy of amyotrophic lateral sclerosis and of myelopathic muscular atrophy]. Rass Int Clin Ter, Vol. 35, No. 6, pp. 197-206. 
Mora, J.S., Munsat, T.L., Kao, K.P., Finison, L.J., Hedlund, W., Bradley, G.A., Scheife, R. \& Georgiades, J.A. (1986). Intrathecal administration of natural human interferon alpha in amyotrophic lateral sclerosis. Neurology, Vol. 36, No. 8, pp. 1137-1140.

Mück-Seler, D. \& Pivac, N. (2000). TCH-346 (Novartis). IDrugs, Vol. 3, No. 5, pp. 530-535.

Munsat, T.L., Easterday, C.S., Levy, S., Wolff, S.M. \& Hiatt, R. (1981). Amantadine and guanidine are ineffective in ALS. Neurology, Vol. 31, No. 8, pp. 1054-1055.

Munsat, T.L., Taft, J., Jackson, I.M., Andres, P.L., Hollander, D., Skerry, L., Ordman, M., Kasdon, D. \& Finison, L. (1992). Intrathecal thyrotropin-releasing hormone does not alter the progressive course of ALS: experience with an intrathecal drug delivery system. Neurology, Vol. 42, No. 5, pp. 1049-1053.

Nakano, I. (2000). Frontotemporal dementia with motor neuron disease (amyotrophic lateral sclerosis with dementia). Neuropathology, Vol. 20, No. 1, pp. 68-75.

Nandedkar, S.D., Barkhaus, P.E. \& Stalberg, E.V. (2010). Motor unit number index (MUNIX): principle, method, and findings in healthy subjects and in patients with motor neuron disease. Muscle Nerve, Vol. 42, No. 5, pp. 798-807.

Nefussy, B., Artamonov, I., Deutsch, V., Naparstek, E., Nagler, A. \& Drory, V.E. (2010). Recombinant human granulocyte-colony stimulating factor administration for treating amyotrophic lateral sclerosis: A pilot study. Amyotroph Lateral Scler, Vol. 11, No. 1-2, pp. 187-193.

Neuwirth, C., Nandedkar, S., Stalberg, E., Barkhaus, P.E., Carvalho, M.D., Furtula, J., Dijk, J.P., Baldinger, R., Castro, J., Costa, J., Otto, M., Sandberg, A. \& Weber, M. (2011). Motor Unit Number Index (MUNIX): A novel neurophysiological marker for neuromuscular disorders; test-retest reliability in healthy volunteers. Clin Neurophysiol, Vol. 2011, pp. 9.

Norris, F.H., Jr., Calanchini, P.R., Fallat, R.J., Panchari, S. \& Jewett, B. (1974). The administration of guanidine in amyotrophic lateral sclerosis. Neurology, Vol. 24, No. 8, pp. 721-728.

Norris, F.H., Jr., Fallat, R.J. \& Calanchini, P.R. (1974). Increased paralysis induced by guanidine in motor neuron disease. Neurology, Vol. 24, No. 2, pp. 135-137.

Norris, F.H., Tan, Y., Fallat, R.J. \& Elias, L. (1993). Trial of oral physostigmine in amyotrophic lateral sclerosis. Clin Pharmacol Ther, Vol. 54, No. 6, pp. 680-682.

Norris, L., Que, G. \& Bayat, E. (2010). Psychiatric aspects of amyotrophic lateral sclerosis (ALS). Curr Psychiatry Rep, Vol. 12, No. 3, pp. 239-245.

Ochs, G., Penn, R.D., York, M., Giess, R., Beck, M., Tonn, J., Haigh, J., Malta, E., Traub, M., Sendtner, M. \& Toyka, K.V. (2000). A phase I/II trial of recombinant methionyl human brain derived neurotrophic factor administered by intrathecal infusion to patients with amyotrophic lateral sclerosis. Amyotroph Lateral Scler Other Motor Neuron Disord, Vol. 1, No. 3, pp. 201-206.

Olarte, M.R., Gersten, J.C., Zabriskie, J. \& Rowland, L.P. (1979). Transfer factor is ineffective in amyotrophic lateral sclerosis. Ann Neurol, Vol. 5, No. 4, pp. 385-388.

Olarte, M.R. \& Shafer, S.Q. (1985). Levamisole is ineffective in the treatment of amyotrophic lateral sclerosis. Neurology, Vol. 35, No. 7, pp. 1063-1066.

Oliveira, A.S. \& Pereira, R.D. (2009). Amyotrophic lateral sclerosis (ALS): three letters that change the people's life. For ever. Arq Neuropsiquiatr, Vol. 67, No. 3A, pp. 750-782.

Olney, N. \& Rosen, H. (2010). AVP-923, a combination of dextromethorphan hydrobromide and quinidine sulfate for the treatment of pseudobulbar affect and neuropathic pain. IDrugs, Vol. 13, No. 4, pp. 254-265. 
Olson, W.H., Simons, J.A. \& Halaas, G.W. (1978). Therapeutic trial of tilorone in ALS: lack of benefit in a double-blind, placebo-controlled study. Neurology, Vol. 28, No. 12, pp. 1293-1295.

Orrell, R.W. (2006). AEOL-10150 (Aeolus). Curr Opin Investig Drugs, Vol. 7, No. 1, pp. 70-80.

Orrell, R.W., Lane, R.J. \& Ross, M. (2008). A systematic review of antioxidant treatment for amyotrophic lateral sclerosis/motor neuron disease. Amyotroph Lateral Scler, Vol. 9, No. 4, pp. 195-211.

Pascuzzi, R.M., Shefner, J., Chappell, A.S., Bjerke, J.S., Tamura, R., Chaudhry, V., Clawson, L., Haas, L. \& Rothstein, J.D. (2010). A phase II trial of talampanel in subjects with amyotrophic lateral sclerosis. Amyotroph Lateral Scler, Vol. 11, No. 3, pp. 266-271.

Pasinelli, P. \& Brown, R.H. (2006). Molecular biology of amyotrophic lateral sclerosis: insights from genetics. Nat Rev Neurosci, Vol. 7, No. 9, pp. 710-723.

Patrignani, J., Proano, J. \& Morales, M.D. (1992). [Treatment of amyotrophic lateral sclerosis with daily intrathecal TRH. A year's experience. Pilot study II]. Neurologia, Vol. 7, No. 1, pp. 4-9.

Pattee, G.L., Post, G.R., Gerber, R.E. \& Bennett, J.P., Jr. (2003). Reduction of oxidative stress in amyotrophic lateral sclerosis following pramipexole treatment. Amyotroph Lateral Scler Other Motor Neuron Disord, Vol. 4, No. 2, pp. 90-95.

Percy, A.K., Davis, L.E., Johnston, D.M. \& Drachman, D.B. (1971). Failure of isoprinosine in amyotropic lateral sclerosis. N Engl J Med, Vol. 285, No. 12, pp. 689.

Phukan, J. (2010). Arimoclomol, a coinducer of heat shock proteins for the potential treatment of amyotrophic lateral sclerosis. IDrugs, Vol. 13, No. 7, pp. 482-496.

Piepers, S., Veldink, J.H., de Jong, S.W., van der Tweel, I., van der Pol, W.L., Uijtendaal, E.V., Schelhaas, H.J., Scheffer, H., de Visser, M., de Jong, J.M., Wokke, J.H., Groeneveld, G.J. \& van den Berg, L.H. (2009). Randomized sequential trial of valproic acid in amyotrophic lateral sclerosis. Ann Neurol, Vol. 66, No. 2, pp. 227-234.

Pradat, P.F., Attarian, S., Camdessanche, J.P., Carluer, L., Cintas, P., Corcia, P., EchanizLaguna, A., Gonzalez-Bermejo, J., Guy, N., Nicolas, G., Perez, T., Soriani, M.H., Vandenberghe, N. \& Verschueren, A. (2010). [Research in amyotrophic lateral sclerosis: what is new in 2009?]. Rev Neurol (Paris), Vol. 166, No. 8-9, pp. 683-698.

Rapport, M.M. (1990). Implications of altered brain ganglioside profiles in amyotrophic lateral sclerosis (ALS). Acta Neurobiol Exp (Wars), Vol. 50, No. 4-5, pp. 505-513.

Rivera, V.M., Grabois, M., Deaton, W., Breitbach, W. \& Hines, M. (1980). Modified snake venom in amyotrophic lateral sclerosis. Lack of clinical effectiveness. Arch Neurol, Vol. 37, No. 4, pp. 201-203.

Robberecht, W. (2002). Genetics of familial amyotrophic lateral sclerosis and ethical aspects, In: Motor Neuron Disease, Kuncl, R.W. (Eds.), pp. 75-93, Saunders, Philadelphia, PA.

Rodrigues, C.M., Spellman, S.R., Sola, S., Grande, A.W., Linehan-Stieers, C., Low, W.C. \& Steer, C.J. (2002). Neuroprotection by a bile acid in an acute stroke model in the rat. J Cereb Blood Flow Metab, Vol. 22, No. 4, pp. 463-471.

Rosenbloom, A.L. (2009). Mecasermin (recombinant human insulin-like growth factor I). Adv Ther, Vol. 26, No. 1, pp. 40-54.

Rosenfeld, J., King, R.M., Jackson, C.E., Bedlack, R.S., Barohn, R.J., Dick, A., Phillips, L.H., Chapin, J., Gelinas, D.F. \& Lou, J.S. (2008). Creatine monohydrate in ALS: effects on strength, fatigue, respiratory status and ALSFRS. Amyotroph Lateral Scler, Vol. 9, No. 5, pp. 266-272. 
Ross, E. (2009). Unapproved drug use: compassionate or cause for concern? Lancet Neurol, Vol. 8, No. 2, pp. 136-137.

Ross, M.A., Miller, R.G., Berchert, L., Parry, G., Barohn, R.J., Armon, C., Bryan, W.W., Petajan, J., Stromatt, S., Goodpasture, J. \& McGuire, D. (1998). Toward earlier diagnosis of amyotrophic lateral sclerosis: revised criteria. rhCNTF ALS Study Group. Neurology, Vol. 50, No. 3, pp. 768-772.

Rowland, L.P. (2001). How amyotrophic lateral sclerosis got its name: the clinical-pathologic genius of Jean-Martin Charcot. Arch Neurol, Vol. 58, No. 3, pp. 512-515.

Rowland, L.P. (2009). T.L. Bunina, Asao Hirano, and the post mortem cellular diagnosis of amyotrophic lateral sclerosis. Amyotroph Lateral Scler, Vol. 10, No. 2, pp. 74-78.

Ryberg, H., Askmark, H. \& Persson, L.I. (2003). A double-blind randomized clinical trial in amyotrophic lateral sclerosis using lamotrigine: effects on CSF glutamate, aspartate, branched-chain amino acid levels and clinical parameters. Acta Neurol Scand, Vol. 108, No. 1, pp. 1-8.

Sacca, F., Quarantelli, M., Rinaldi, C., Tucci, T., Piro, R., Perrotta, G., Carotenuto, B., Marsili, A., Palma, V., De Michele, G., Brunetti, A., Brescia Morra, V., Filla, A. \& Salvatore, M. (2011). A randomized controlled clinical trial of growth hormone in amyotrophic lateral sclerosis: clinical, neuroimaging, and hormonal results. J Neurol, Vol. 2011, pp. [Epub ahead of print].

Sathasivam, S. (2010). Motor neurone disease: clinical features, diagnosis, diagnostic pitfalls and prognostic markers. Singapore Med J, Vol. 51, No. 5, pp. 367-372; quiz 373.

Sathasivam, S., Ince, P.G. \& Shaw, P.J. (2001). Apoptosis in amyotrophic lateral sclerosis: a review of the evidence. Neuropathol Appl Neurobiol, Vol. 27, No. 4, pp. 257-274.

Scelsa, S.N., MacGowan, D.J., Mitsumoto, H., Imperato, T., LeValley, A.J., Liu, M.H., DelBene, M. \& Kim, M.Y. (2005). A pilot, double-blind, placebo-controlled trial of indinavir in patients with ALS. Neurology, Vol. 64, No. 7, pp. 1298-1300.

Schwob, R.A. \& Bonduelle, M. (1952). [Trypan blue and trypan red in the treatment of amyotrophic lateral sclerosis; application to the treatment of multiple sclerosis]. Sem Hop, Vol. 28, No. 39, pp. 1637-1642.

Scott, S., Kranz, J.E., Cole, J., Lincecum, J.M., Thompson, K., Kelly, N., Bostrom, A., Theodoss, J., Al-Nakhala, B.M., Vieira, F.G., Ramasubbu, J. \& Heywood, J.A. (2008). Design, power, and interpretation of studies in the standard murine model of ALS. Amyotroph Lateral Scler, Vol. 9, No. 1, pp. 4-15.

Serratrice, G., Desnuelle, C., Guelton, C., Meyer-Dutour, A., Richard, P., Braguer, D. \& Crevat, A. (1985). [Trial of thyrotropin-releasing factor in amyotrophic lateral sclerosis]. Presse Med, Vol. 14, No. 8, pp. 487-488.

Shefner, J.M., Cudkowicz, M.E., Schoenfeld, D., Conrad, T., Taft, J., Chilton, M., Urbinelli, L., Qureshi, M., Zhang, H., Pestronk, A., Caress, J., Donofrio, P., Sorenson, E., Bradley, W., Lomen-Hoerth, C., Pioro, E., Rezania, K., Ross, M., Pascuzzi, R., HeimanPatterson, T., Tandan, R., Mitsumoto, H., Rothstein, J., Smith-Palmer, T., MacDonald, D. \& Burke, D. (2004). A clinical trial of creatine in ALS. Neurology, Vol. 63, No. 9, pp. 1656-1661.

Shefner, J.M., Watson, M.L., Simionescu, L., Caress, J.B., Burns, T.M., Maragakis, N.J., Benatar, M., David, W.S., Sharma, K.R. \& Rutkove, S.B. (2011). Multipoint incremental motor unit number estimation as an outcome measure in ALS. Neurology, Vol. 2011, No. [epub ahead of print], pp. 15. 
Shi, P., Gal, J., Kwinter, D.M., Liu, X. \& Zhu, H. (2010). Mitochondrial dysfunction in amyotrophic lateral sclerosis. Biochim Biophys Acta, Vol. 1802, No. 1, pp. 45-51.

Siciliano, G., Carlesi, C., Pasquali, L., Piazza, S., Pietracupa, S., Fornai, F., Ruggieri, S. \& Murri, L. (2010). Clinical trials for neuroprotection in ALS. CNS Neurol Disord Drug Targets, Vol. 9, No. 3, pp. 305-313.

Silani, V., Meininger, V. \& Fornai, F. (2011). Introducing Amyotrophic lateral sclerosis. Arch Ital Biol, Vol. 149, No. 1, pp. 1-4.

Silani, V., Messina, S., Poletti, B., Morelli, C., Doretti, A., Ticozzi, N. \& Maderna, L. (2011). The diagnosis of Amyotrophic lateral sclerosis in 2010. Arch Ital Biol, Vol. 149, No. 1, pp. 5-27.

Silani, V., Perini, M., Fayoumi, Z.M. \& Scarlato, G. (1983). Naloxone of no benefit in amyotrophic lateral sclerosis. Ann Neurol, Vol. 13, No. 2, pp. 222.

Sleegers, K., Cruts, M. \& Van Broeckhoven, C. (2010). Molecular pathways of frontotemporal lobar degeneration. Annu Rev Neurosci, Vol. 33, pp. 71-88.

Smith, R.A., Miller, T.M., Yamanaka, K., Monia, B.P., Condon, T.P., Hung, G., Lobsiger, C.S., Ward, C.M., McAlonis-Downes, M., Wei, H., Wancewicz, E.V., Bennett, C.F. \& Cleveland, D.W. (2006). Antisense oligonucleotide therapy for neurodegenerative disease. J Clin Invest, Vol. 116, No. 8, pp. 2290-2296.

Sorenson, E.J., Windbank, A.J., Mandrekar, J.N., Bamlet, W.R., Appel, S.H., Armon, C., Barkhaus, P.E., Bosch, P., Boylan, K., David, W.S., Feldman, E., Glass, J., Gutmann, L., Katz, J., King, W., Luciano, C.A., McCluskey, L.F., Nash, S., Newman, D.S., Pascuzzi, R.M., Pioro, E., Sams, L.J., Scelsa, S., Simpson, E.P., Subramony, S.H., Tiryaki, E. \& Thornton, C.A. (2008). Subcutaneous IGF-1 is not beneficial in 2-year ALS trial. Neurology, Vol. 71, No. 22, pp. 1770-1775.

Stober, T., Schimrigk, K., Dietzsch, S. \& Thielen, T. (1985). Intrathecal thyrotropin-releasing hormone therapy of amyotrophic lateral sclerosis. J Neurol, Vol. 232, No. 1, pp. 1314.

Stommel, E.W., Cohen, J.A., Fadul, C.E., Cogbill, C.H., Graber, D.J., Kingman, L., Mackenzie, T., Channon Smith, J.Y. \& Harris, B.T. (2009). Efficacy of thalidomide for the treatment of amyotrophic lateral sclerosis: a phase II open label clinical trial. Amyotroph Lateral Scler, Vol. 10, No. 5-6, pp. 393-404.

Szulc-Kuberska, J., Klimek, A., Stepien, H. \& Woszczak, M. (1990). [Clinical trial of the treatment of amyotrophic lateral sclerosis with bromocriptine]. Neurol Neurochir Pol, Vol. 24, No. 1-2, pp. 37-41.

Takahashi, R. (2009). Edaravone in ALS. Exp Neurol, Vol. 217, No. 2, pp. 235-236.

Tandan, R., Bromberg, M.B., Forshew, D., Fries, T.J., Badger, G.J., Carpenter, J., Krusinski, P.B., Betts, E.F., Arciero, K. \& Nau, K. (1996). A controlled trial of amino acid therapy in amyotrophic lateral sclerosis: I. Clinical, functional, and maximum isometric torque data. Neurology, Vol. 47, No. 5, pp. 1220-1226.

Thatte, U. \& Dahanukar, S. (1997). Apoptosis: clinical relevance and pharmacological manipulation. Drugs, Vol. 54, No. 4, pp. 511-532.

The ALS CNTF treatment study (ACTS) phase I-II Study Group. (1996). The Amyotrophic Lateral Sclerosis Functional Rating Scale. Assessment of activities of daily living in patients with amyotrophic lateral sclerosis. . Arch Neurol, Vol. 53, No. 2, pp. 141147.

The BDNF Study Group (Phase III). (1999). A controlled trial of recombinant methionyl human BDNF in ALS. Neurology, Vol. 52, No. 7, pp. 1427-1433. 
Thielen, T., Stober, T. \& Schimrigk, K. (1987). Therapeutic trial of intrathecal thyrotropinreleasing hormone (TRH) and a TRH-analogue in amyotrophic lateral sclerosis (ALS). Adv Exp Med Biol, Vol. 209, pp. 305-308.

Ticozzi, N., Tiloca, C., Morelli, C., Colombrita, C., Poletti, B., Doretti, A., Maderna, L., Messina, S., Ratti, A. \& Silani, V. (2011). Genetics of familial Amyotrophic lateral sclerosis. Arch Ital Biol, Vol. 149, No. 1, pp. 65-82.

Traynor, B.J., Alexander, M., Corr, B., Frost, E. \& Hardiman, O. (2003). An outcome study of riluzole in amyotrophic lateral sclerosis--a population-based study in Ireland, 19962000. J Neurol, Vol. 250, No. 4, pp. 473-479.

Traynor, B.J., Bruijn, L., Conwit, R., Beal, F., O'Neill, G., Fagan, S.C. \& Cudkowicz, M.E. (2006). Neuroprotective agents for clinical trials in ALS: a systematic assessment. Neurology, Vol. 67, No. 1, pp. 20-27.

Tsujimoto, M., Senda, J., Ishihara, T., Niimi, Y., Kawai, Y., Atsuta, N., Watanabe, H., Tanaka, F., Naganawa, S. \& Sobue, G. (2011). Behavioral changes in early ALS correlate with voxel-based morphometry and diffusion tensor imaging. J Neurol Sci, Vol. 307, No. 1-2, pp. 34-40.

Turner, M.R., Grosskreutz, J., Kassubek, J., Abrahams, S., Agosta, F., Benatar, M., Filippi, M., Goldstein, L.H., van den Heuvel, M., Kalra, S., Lule, D. \& Mohammadi, B. (2011). Towards a neuroimaging biomarker for amyotrophic lateral sclerosis. Lancet Neurol, Vol. 10, No. 5, pp. 400-403.

Valentine, J.S., Doucette, P.A. \& Zittin Potter, S. (2005). Copper-zinc superoxide dismutase and amyotrophic lateral sclerosis. Annu Rev Biochem, Vol. 74, pp. 563-593.

van der Meer, J.W. \& Simon, A. (2010). Blocking IL-1beta to slow down progression of ALS? Proc Natl Acad Sci U S A, Vol. 107, No. 29, pp. 12741-12742.

Veldink, J.H., Kalmijn, S., Groeneveld, G.J., Wunderink, W., Koster, A., de Vries, J.H., van der Luyt, J., Wokke, J.H. \& Van den Berg, L.H. (2007). Intake of polyunsaturated fatty acids and vitamin $\mathrm{E}$ reduces the risk of developing amyotrophic lateral sclerosis. J Neurol Neurosurg Psychiatry, Vol. 78, No. 4, pp. 367-371.

von Haehling, S., Stepney, R. \& Anker, S.D. (2010). Advances in understanding and treating cardiac cachexia: highlights from the 5th Cachexia Conference. Int J Cardiol, Vol. 144, No. 3, pp. 347-349.

Wang, H., Larriviere, K.S., Keller, K.E., Ware, K.A., Burns, T.M., Conaway, M.A., Lacomis, D., Pattee, G.L., Phillips, L.H., 2nd, Solenski, N.J., Zivkovic, S.A. \& Bennett, J.P., Jr. (2008). R+ pramipexole as a mitochondrially focused neuroprotectant: initial early phase studies in ALS. Amyotroph Lateral Scler, Vol. 9, No. 1, pp. 50-58.

Weber, M., Goldman, B. \& Truniger, S. (2010). Tetrahydrocannabinol (THC) for cramps in amyotrophic lateral sclerosis: a randomised, double-blind crossover trial. J Neurol Neurosurg Psychiatry, Vol. 81, No. 10, pp. 1135-1140.

Welty, D.F., Schielke, G.P. \& Rothstein, J.D. (1995). Potential treatment of amyotrophic lateral sclerosis with gabapentin: a hypothesis. Ann Pharmacother, Vol. 29, No. 11, pp. 1164-1167.

Werdelin, L., Boysen, G., Jensen, T.S. \& Mogensen, P. (1990). Immunosuppressive treatment of patients with amyotrophic lateral sclerosis. Acta Neurol Scand, Vol. 82, No. 2, pp. 132-134.

Westarp, M.E., Bartmann, P., Rossler, J., Geiger, E., Westphal, K.P., Schreiber, H., Fuchs, D., Westarp, M.P. \& Kornhuber, H.H. (1993). Antiretroviral therapy in sporadic adult amyotrophic lateral sclerosis. Neuroreport, Vol. 4, No. 6, pp. 819-822. 
Weydt, P. \& Moller, T. (2005). Neuroinflammation in the pathogenesis of amyotrophic lateral sclerosis. Neuroreport, Vol. 16, No. 6, pp. 527-531.

Wijesekera, L.C. \& Leigh, P.N. (2009). Amyotrophic lateral sclerosis. Orphanet J Rare Dis, Vol. 4, No. 3, pp. 3.

Williams, M.T., Donnelly, J.P., Holmlund, T. \& Battaglia, M. (2008). ALS: Family caregiver needs and quality of life. Amyotroph Lateral Scler, Vol. 9, No. 5, pp. 279-286.

Witgert, M., Salamone, A.R., Strutt, A.M., Jawaid, A., Massman, P.J., Bradshaw, M., Mosnik, D., Appel, S.H. \& Schulz, P.E. (2009). Frontal-lobe mediated behavioral dysfunction in amyotrophic lateral sclerosis. Eur J Neurol, Vol. 17, No. 1, pp. 103-110.

Woolley, S.C. \& Jonathan, S.K. (2008). Cognitive and behavioral impairment in amyotrophic lateral sclerosis. Phys Med Rehabil Clin N Am, Vol. 19, No. 3, pp. 607-617, xi.

Worrall, B.B., Rowland, L.P., Chin, S.S. \& Mastrianni, J.A. (2000). Amyotrophy in prion diseases. Arch Neurol, Vol. 57, No. 1, pp. 33-38.

Yamane, K., Osawa, M., Kobayashi, I. \& Maruyama, S. (1986). Treatment of amyotrophic lateral sclerosis with thyrotropin-releasing hormone (TRH). Jpn J Psychiatry Neurol, Vol. 40, No. 2, pp. 179-187.

Yase, Y., Matsumoto, N., Azuma, K., Nakai, Y. \& Shiraki, H. (1972). Amyotrophic lateral sclerosis. Association with schizophrenic symptoms and showing Alzheimer's tangles. Arch Neurol, Vol. 27, No. 2, pp. 118-128.

Yoshida, M. (2004). Amyotrophic lateral sclerosis with dementia: the clinicopathological spectrum. Neuropathology, Vol. 24, No. 1, pp. 87-102.

Yoshino, H. \& Kimura, A. (2006). Investigation of the therapeutic effects of edaravone, a free radical scavenger, on amyotrophic lateral sclerosis (Phase II study). Amyotroph Lateral Scler, Vol. 7, No. 4, pp. 241-245.

Zago, S., Poletti, B., Morelli, C., Doretti, A. \& Silani, V. (2011). Amyotrophic lateral sclerosis and frontotemporal dementia (ALS-FTD). Arch Ital Biol, Vol. 149, No. 1, pp. 39-56.

Zhang, Y., Wang, L., Fu, Y., Song, H., Zhao, H., Deng, M., Zhang, J. \& Fan, D. (2009). Preliminary investigation of effect of granulocyte colony stimulating factor on amyotrophic lateral sclerosis. Amyotroph Lateral Scler, Vol. 10, No. 5-6, pp. 430-431.

Zinman, L. \& Cudkowicz, M. (2011). Emerging targets and treatments in amyotrophic lateral sclerosis. Lancet Neurol, Vol. 10, No. 5, pp. 481-490.

Zoccolella, S., Beghi, E., Palagano, G., Fraddosio, A., Guerra, V., Samarelli, V., Lepore, V., Simone, I.L., Lamberti, P., Serlenga, L. \& Logroscino, G. (2007). Riluzole and amyotrophic lateral sclerosis survival: a population-based study in southern Italy. Eur J Neurol, Vol. 14, No. 3, pp. 262-268.

Zoccolella, S., Santamato, A. \& Lamberti, P. (2009). Current and emerging treatments for amyotrophic lateral sclerosis. Neuropsychiatr Dis Treat, Vol. 5, pp. 577-595. 
AMYOTROPHIC

LATERAL SCLEROSIS

Eaced by Marton H. maver

\section{Amyotrophic Lateral Sclerosis}

Edited by Prof. Martin Maurer
ISBN 978-953-307-806-9

Hard cover, 718 pages

Publisher InTech

Published online 20, January, 2012

Published in print edition January, 2012

Though considerable amount of research, both pre-clinical and clinical, has been conducted during recent years, Amyotrophic Lateral Sclerosis (ALS) remains one of the mysterious diseases of the 21st century. Great efforts have been made to develop pathophysiological models and to clarify the underlying pathology, and with novel instruments in genetics and transgenic techniques, the aim for finding a durable cure comes into scope. On the other hand, most pharmacological trials failed to show a benefit for ALS patients. In this book, the reader will find a compilation of state-of-the-art reviews about the etiology, epidemiology, and pathophysiology of ALS, the molecular basis of disease progression and clinical manifestations, the genetics familial ALS, as well as novel diagnostic criteria in the field of electrophysiology. An overview over all relevant pharmacological trials in ALS patients is also included, while the book concludes with a discussion on current advances and future trends in ALS research.

\section{How to reference}

In order to correctly reference this scholarly work, feel free to copy and paste the following:

Martin H. Maurer (2012). Amyotrophic Lateral Sclerosis: An Introduction to Treatment and Trials, Amyotrophic Lateral Sclerosis, Prof. Martin Maurer (Ed.), ISBN: 978-953-307-806-9, InTech, Available from:

http://www.intechopen.com/books/amyotrophic-lateral-sclerosis/amyotrophic-lateral-sclerosis-an-introductionto-treatment-and-trials

\section{INTECH}

open science | open minds

\section{InTech Europe}

University Campus STeP Ri

Slavka Krautzeka 83/A

51000 Rijeka, Croatia

Phone: +385 (51) 770447

Fax: +385 (51) 686166

www.intechopen.com

\section{InTech China}

Unit 405, Office Block, Hotel Equatorial Shanghai

No.65, Yan An Road (West), Shanghai, 200040, China 中国上海市延安西路65号上海国际贵都大饭店办公楼 405 单元

Phone: +86-21-62489820

Fax: $+86-21-62489821$ 
(C) 2012 The Author(s). Licensee IntechOpen. This is an open access article distributed under the terms of the Creative Commons Attribution 3.0 License, which permits unrestricted use, distribution, and reproduction in any medium, provided the original work is properly cited. 